\title{
A Beleza está nos OlHos de QueM a VÊ? A PERCEPÇÃO DE REALIDADES ABSTRATAS
}

\author{
LUIZ HENRIQUE DE ARAúJo DUTRA
}

\begin{abstract}
This paper argues for a version of perspectival realism as to abstract objects. Differently from bodies and mental states, abstract realities are supposed to be always unobservable objects, things never given in perception. Contrary to this received view, this paper tries to show that abstract objects can be perceived, even though people aren't currently aware of perceiving them. Moreover, in order to perceive abstract objects we must be accordingly equipped. Our equipment to perceive abstract objects involves not only retino-cortical elements, but mental and cultural conditions as well.
\end{abstract}

Keywords: Abstract realities; perspectivism; realism; perception.

Se olhamos para o céu à noite e vemos uma constelação - o Cruzeiro do Sul, digamos —, não vamos dizer que vemos apenas cinco estrelas; vemos a constelação. Essas estrelas, aliás, é o que menos vemos nesse caso, mas também não podemos dizer que vemos apenas um brilho e que inferimos que ele provém de uma estrela situada anosluz da Terra, embora isso também seja verdade. De qualquer modo, a constelação é algo mais nitidamente observável do que cada uma de suas estrelas. É verdade que podemos ver as estrelas (ou seu brilho, se quisermos assim) e não percebermos a constelação. Assim, ver a constelação requer estar também de posse de um conceito, ao passo que ver as estrelas parece que não. Mas apenas parece!

Um exemplo semelhante é o de olharmos para um bosque à distância. Analiticamente falando, o bosque não existe a não ser porque reúne diversas árvores. Mas a partir de certa distância, percebemos o bosque, e não cada uma de suas árvores. Se não tivermos o conceito de bosque para podermos perceber o bosque, e se não pudermos ver distintamente as árvores, vemos ou percebemos apenas uma mancha ou uma série de manchas, de diversas cores, e reunidas naquela massa indistinta e disforme que quem tem o conceito de bosque pode chamar de bosque e dizer que o percebe, assim como quem tem o conceito de árvore percebe cada uma das árvores do bosque, se estiver perto o suficiente.

Tomemos agora um exemplo que envolve um ser humano visto ou percebido. Se vemos um rosto sorridente, que expressa claramente alegria, não dizemos que vemos determinadas curvas na pele desse rosto, curvas provocadas por contrações musculares que, essas, não vemos. Dizemos ou que vemos um sorriso, ou uma pessoa alegre. É claro que para tudo isso também é preciso ter os conceitos adequados.

Principia 21(2): 251-289 (2017).

Published by NEL — Epistemology and Logic Research Group, Federal University of Santa Catarina (UFSC), Brazil. 
Podemos dizer que seu sorriso expressa tal emoção. O rosto humano é uma espécie de espelho da mente, como se costuma dizer - e muitas pesquisas atuais analisam detalhadamente esses padrões faciais que nos permitem conhecer os estados mentais das pessoas. ${ }^{1}$ A concepção padrão nesse caso é que vemos o sorriso da pessoa e que inferimos sua emoção, sendo essa última uma realidade inobservável. Mas também dizemos que vemos uma pessoa feliz, e, logo, que vemos uma pessoa, enquanto que, estritamente falando, segundo essa forma de entender a percepção e seus objetos, o que vemos é seu corpo, um objeto material. Mas nos restringirmos a isso seria tomar a postura de um empirismo exagerado.

Consideremos agora um último exemplo: dois indivíduos que se cumprimentam na rua, passando um pelo outro, quem sabe apenas acenando um para o outro com a mão. Nesse contexto, não parece ser problemático dizer que vemos as duas pessoas, assim como vemos suas mãos que se movimentam. A concepção padrão que mencionamos acima afirma que não vemos suas respectivas intenções de se comunicarem, os estados mentais que motivaram os movimentos de suas mãos. Mas essa concepção dificilmente nos impedirá de dizer que percebemos a saudação entre essas duas pessoas. Essa saudação entre elas é uma realidade social, além de poder ser motivada por realidades mentais em cada uma dessas pessoas. E enquanto essas realidades mentais podem permanecer ocultas, a saudação é um evento público e observável. Entretanto, ela é também uma realidade abstrata, como são todas as realidades sociais ou culturais. E é claro que falar dela também requer conceitos apropriados. Seria de um extremo pedantismo empirista dizermos que vemos apenas as mãos das pessoas a se movimentarem - e que inferimos que houve ali uma saudação. É claro que vemos a saudação. Ela também é um objeto de percepção.

Resumindo ideias que transparecem nos comentários acima, segundo a concepção comum dos filósofos, sobretudo os empiristas, dizemos que as realidades físicas (ou materiais) são objetos de percepção, no sentido de percepção sensorial. As realidades psíquicas também podem ser passíveis de um tipo de percepção interna, da parte do próprio sujeito, que não é, contudo, uma percepção sensorial, isto é, ligada aos cinco sentidos externos. As realidades abstratas, por sua vez, se são mesmo "realidades" - e não meras ficções —, podem ser inferidas, mas não percebidas. Elas são, por assim dizer, entes de pensamento, não de experiência. Desejamos sustentar, contudo, que as realidades abstratas são também objetos de percepção.

Uma das razões para recusar às realidades abstratas o status de entes de percepção é que sua existência seria meramente perspectivista, tese essa, aliás, que não desejamos contestar, mas apoiar. Contudo, as próprias realidades físicas existem também apenas de forma perspectivista. O realismo perspectivista, que tem sido considerado uma forma de resgatar a tese platônica da existência objetiva de objetos abstratos, se aplica também ao caso dos objetos físicos. Esse realismo perspectivista é uma forma de neokantismo, e rejeita também o idealismo, não apenas o materialismo ingênuo, 
colocando em pé de igualdade ontológica os objetos abstratos e os objetos físicos.

Assim, se as realidades físicas são objetos de percepção externa, igualmente, as realidades abstratas (os objetos culturais) o são. Essa posição só é, contudo, sustentável se revisarmos a própria concepção de percepção, que deve ser considerada parte de um processo cognitivo mais amplo. Segundo essa concepção alternativa, a percepção não se opõe ao pensamento ou à cognição, mas é parte do processo de cognição que é essencialmente o mesmo tanto no caso de objetos físicos, quanto no caso de objetos abstratos e, como não poderia deixar de ser, também de objetos psíquicos.

\section{Ser é ser percebido?}

"A beleza está nos olhos que quem a vê" é um dito popular que comporta diferentes interpretações. Uma delas é em viés relativista, dizendo respeito ao fato de que pessoas diferentes discordam sobre determinados aspectos qualitativos das coisas. Essa interpretação diz respeito às questões de gosto, às diferenças culturais, aos diferentes valores e conceitos aplicados às coisas, sendo eles considerados inteiramente distintos daquelas coisas às quais se aplicam. São distintos no sentido de que tais coisas podem ser pensadas independentemente de tais valores e conceitos, é verdade. Elas podem ser pensadas e entendidas mediante outros conceitos que, esses sim, por sua vez, são neutros em relação a quaisquer perspectivas particulares, a quaisquer culturas, pontos de vista, gostos, idiossincrasias etc. Esses últimos são tradicionalmente considerados os conceitos puramente quantitativos que empregamos na descrição das coisas materiais. Assim, se o que temos em conta são os aspectos não quantitativos, mas qualitativos, das coisas - aquilo que, por assim dizer, nos enche os olhos e nos faz experimentar uma espécie de prazer meio sensorial, meio intelectual, como a contemplação de um objeto que julgamos belo, desejável etc. —, isso não vai produzir necessariamente os mesmos efeitos em outras pessoas; e pode mesmo produzir efeitos opostos.

Assim, por exemplo, para fugirmos um pouco do domínio dos filósofos e darmos atenção a outros para os quais esses temas também têm importância, podemos ver Lima Barreto em um de seus contos dizendo o seguinte:

Daí concluí, não sem ligeireza, que essa nossa mania de beleza é um contágio dos delirantes sonhos de alguns homens, dados a loucuras de Arte, exacerbados com os delírios das tradições de antigas raças e sofrendo a tirania dos ideais belos; é que as nossas sensações são interpretadas pelo nosso entendimento, de acordo com as imagens de certos padrões, que já estamos predispostos a recebê-las ... (Barreto 2010, "Uma conversa".)

É interessante notarmos nessa passagem a menção de "padrões" de beleza segundo os quais nosso entendimento interpreta o que vemos, pois isso tem muito a 
ver com nossa discussão aqui. Concordamos que nossas sensações são interpretadas. E, além disso, que tais padrões são realidades culturais e, portanto, abstratas. Mas não adiantemos as coisas.

Exportada do domínio estético para o moral, apesar de reconhecermos a relatividade dos preceitos morais em relação aos valores culturais, essa forma de ver as coisas no mundo pode levar a consequências devastadoras para a convivência humana. Ela preserva individualidades e particularidades culturais, mas pode ser usada para fugir de obrigações e responsabilidades. Mas deixemos de lado essas questões éticas que são, certamente, de primeira ordem, mas que não são as únicas que podem preocupar o filósofo, nem aquelas que estão diretamente envolvidas na percepção de realidades físicas. Elas estão, de qualquer modo, como veremos, envolvidas na "percepção" de realidades abstratas - ainda que, por ora, deixemos o termo entre aspas.

"A beleza está nos olhos de quem a vê" também comporta interpretações menos radicais, digamos, interpretações que não implicam qualquer relativismo, mas apenas diferenças mais leves - e talvez bastante sutis — nos juízos de gosto. Por exemplo, preferir olhos azuis aos castanhos e verdes não é algo que implique necessariamente nenhum relativismo; não implica que quem prefere olhos azuis não goste de olhos castanhos ou verdes, ou os despreze; implica apenas que essa pessoa, que pode gostar dos três tipos, por razões que talvez nem mesmo ela saiba, prefere os olhos azuis. Ela é capaz de perceber a beleza dos olhos castanhos e verdes; é capaz de compreender que eles agradem mais a outras pessoas. Mas essa pessoa que prefere olhos azuis apenas os prefere, reconhecendo que os olhos castanhos e verdes também são belos.

Nesse último caso, não podemos dizer que, de fato, a beleza está nos olhos de quem a vê. A beleza de quaisquer olhos - castanhos, verdes e azuis — pode ser atribuída a eles próprios. Apenas certa preferência, cuja origem pode ser mais ou menos consciente, mais ou menos obscura, é atribuída ao sujeito que demonstra tal preferência. O que se pode argumentar aqui então é que é preciso que a comunidade a que pertence esse sujeito compartilhe a opinião de que os olhos humanos são coisas belas. A perspectiva particular, nesse caso, não é do sujeito, mas de sua comunidade epistêmica. Mas a beleza dos olhos - de quaisquer cores ou de algumas delas depende da perspectiva de tal comunidade de sujeitos. E nesse sentido coletivo, a beleza continua a pertencer aos olhos de que a vê. Certas partes do corpo humano são privilegiadas por determinadas culturas como objetos de contemplação, outras partes, por outras culturas.

Todavia, se todos os indivíduos de determinada comunidade epistêmica compartilham certa crença ou valor, esses últimos não podem ser considerados para eles de outro modo a não ser como universais. ${ }^{2}$ É claro que estamos falando de diferentes culturas, de diferentes grupos humanos, e (ainda) não de toda a comunidade humana como uma única comunidade epistêmica. Mas se encontrarmos determinado valor ou crença que seja compartilhado por todos os seres humanos ou pelo menos 
que nenhum deles em sã consciência, como se diz, esteja disposto a pôr em questão, então estaremos diante de uma crença ou de um valor realmente universal. As crenças e os valores, contudo, não nos parecem ser coisas que possam ser universais desse modo, isto é, dizendo respeito a toda a comunidade epistêmica humana.

Crenças e valores são elementos intelectuais de nossa forma humana de ser. Mas as percepções talvez sejam aqueles elementos de nossa vida mental que seriam elevados à categoria de verdadeiros universais. ${ }^{3}$ Aqui temos de supor indivíduos adultos e com suas capacidades de visão, audição etc. dentro de determinados limites, aqueles que vamos considerar a faixa de normalidade sensorial, digamos assim. Contudo, em pelo menos um de nossos sentidos - e justamente aquele que tem sido pela tradição filosófica considerado o mais importante - , a visão, não podemos falar de um padrão universal, ainda que ele diga respeito à grande maioria da população humana. Estamos nos referindo exatamente às várias formas de capacidade visual, incluindo aí não apenas a visão considerada normal (da maioria da população), mas também as diversas formas de daltonismo. Embora os daltônicos dos diversos tipos desviem da maioria de nós na visão das cores, não podemos dizer que sua visão seja defeituosa. Ela é apenas desviante, digamos. Geneticamente, o daltonismo é como aquela capacidade de pessoas que dobram a língua longitudinalmente. Uma parte dos seres humanos não consegue fazer isso, mas tal incapacidade não acarreta qualquer deficiência nem do ponto de vista fisiológico, nem do ponto de vista social - pelo menos em nossa sociedade, pois podemos pensar que pode haver uma sociedade na qual tal capacidade seja altamente valorizada e mesmo tomada como critério de discriminação social positiva, já que parece ser uma habilidade que apenas alguns possuem. ${ }^{4}$

Evolutivamente, do mesmo modo, tanto essa capacidade de dobrar a língua quanto a ausência (ou presença) do daltonismo não parecem fazer diferença significativa. Em suma, uma humanidade de daltônicos, isto é, isenta de tricromatas, como é a maioria da população do planeta, poderia muito bem sobreviver. Ela poderia, por exemplo, ter hábitos alimentares diferentes dos que temos, uma vez que podemos pensar que a escolha de determinados alimentos na natureza pela humanidade primitiva pode ter sido influenciada pelas cores que vemos. Mas se, por exemplo, não fôssemos capazes de distinguir pimentões verdes de pimentões vermelhos, nem por isso nossa sobrevivência estaria em risco. Se, digamos, os pimentões vermelhos fossem venenosos, mais cedo ou mais tarde nos absteríamos de comer pimentões. E não comê-los não ameaçaria nossa sobrevivência como espécie. Mas não sendo venenosos nem os pimentões verdes, nem os vermelhos, essa humanidade toda daltônica poderia apreciá-los sem saber de sua diferença cromática — cromática para os tricromatas, por exemplo, mas não haveria nenhum tricromata para perceber a diferença.

Com relação à visão das cores, como sabemos hoje, há na população humana em geral diversas subpopulações que constituem a esse respeito diferentes comunidades 
cromáticas alternativas. E embora a realidade das cores seja para cada uma delas perspectivista, isso não impede a convivência bem-sucedida dessas diversas comunidades cromáticas. A realidade perspectivista das cores de que estamos falando aqui é o fato de que, por exemplo, a diferença entre vermelho e verde - como duas cores diferentes - existe apenas para os tricromatas, a maioria da população humana. Ela não existe para as diversas subpopulações daltônicas. Mas nenhum tricromata pode deixar de reconhecer a realidade do vermelho e do verde como duas cores diferentes da paleta padrão. Assim, o realismo perspectivista não implica apenas que certas coisas não existem para os não membros de certa comunidade epistêmica, mas também que para os membros dessa comunidade tais coisas são inegáveis, inevitáveis - e por isso são reais. ${ }^{5}$

A noção de realidade do realismo perspectivista é aquela que diz respeito ao inevitável. Se um de nós tentar sair de uma sala não por suas portas e janelas (ou outras aberturas suficientes para isso), mas atravessando as paredes diretamente, não vai conseguir. E não vai poder deixar de reconhecer essas paredes como coisas reais, sólidas, compactas (embora a microfísica nos diga hoje em dia que a maior parte dessas paredes é de vazio). Em certo sentido, podemos dizer que essa é uma noção minimalista de realidade. A realidade é aquilo que se nos impõe de algum modo. As cores vistas por qualquer uma das diversas comunidades cromáticas são reais para os membros das respectivas comunidades.

Como nossas percepções se nos impõem, é forçoso que também consideremos aquelas coisas que as provocam em nós como reais. Essa é, sem dúvida, uma boa razão para sermos empiristas e, talvez, mais exatamente, sensualistas. Mas o que se nos impõe pelos sentidos pode não ser tão confiável assim, como toda a tradição filosófica tem tanto discutido. Para repetirmos a fórmula de Descartes nas Meditações, os sentidos às vezes nos enganam. Hoje isso não seria motivo para defender qualquer tipo de racionalismo ingênuo - e não estamos dizendo que aquele de Descartes fosse ingênuo - , mas apenas para nos darmos conta de que o que os sentidos nos dão, aquilo que é objeto de percepção sensorial, é produto da interação de nosso aparato neurofisiológico (os cinco sentidos e seus órgãos periféricos aí incluídos) e certas partes do mundo. Mas antes da neurofisiologia de hoje, em sua sagacidade psicológica, cognitiva, Kant já tinha afirmado o mesmo, com consequências epistêmicas que vão muito além de sua filosofia crítica.

Ao lermos, por exemplo, uma obra de ficção como Flatland, de Abbott (1992), ficamos desconfortáveis com o fato de que determinados seres poderiam não perceber um mundo espacialmente tridimensional. Pelo menos três de nossos sentidos a saber, a visão, a audição e o tato - concorrem para nos fazer pensar que a realidade física é tridimensional. E por isso nos parece que aqueles seres imaginados por Abbott, que viveriam em um mundo (para eles) unidimensional ou bidimensional, são simplesmente seres cujo aparato perceptivo é defeituoso. E quando a física atual 
nos convida a tomar em consideração hipóteses de que o universo possa ser multidimensional (isto é, especificamente, um universo tetra, ou penta, ou hexadimensional, ou mais), ficamos igualmente desconcertados. Pois a realidade que naturalmente se nos impõe é a tridimensional. Um mundo pentadimensional, por exemplo, para nós não pode ser real, perspectivamente falando. Podemos até pensá-lo, mas não conhecê-lo, nos diria Kant.

O realismo perspectivista tem muito a ver com o kantismo, isto é, com uma forma generalizada de neokantismo, especificamente, uma forma de idealismo não absoluto, embora não exatamente transcendental no sentido kantiano. Ele trata de uma realidade fenomênica tal como Kant a concebeu. Mas esse realismo perspectivista deve se adaptar não apenas aos conhecimentos neurofisiológicos de hoje, mas deve também expandir suas fronteiras para além daquele mundo que, no sentido kantiano, era eminentemente perceptivo. É claro que há também no kantismo uma forma de perspectivismo categorial, dizendo respeito às categorias e princípios do entendimento puro. Mas isso transformou em objeto de conhecimento (no sentido de Kant) apenas os objetos dados na experiência segundo as duas formas puras da sensibilidade apontadas por ele, espaço e tempo - um espaço tridimensional e um tempo unidimensional.

As realidades abstratas não existem nem no espaço, nem no tempo, e por isso, desde Platão até Kant, elas têm sido consideradas realidades acessíveis apenas pelo pensamento, não pela percepção, se é que são acessíveis. Para os mais críticos (em relação a Platão, por exemplo, mas aceitando Kant), a fronteira entre ficção e realidade seria a fronteira entre percepção e pensamento. Há um perspectivismo nisso também, pois o que pode ser percebido é inevitável, o que pode ser pensado não; o que pode ser pensado pode ser apenas ficção. Poder ser evitado não significa que não seja real, significa apenas que não é patentemente real. Mas aqui há um engano, digamos assim. Pois se os sentidos nos enganam às vezes, o que é patentemente real pode também não existir. Os sonhos que todos temos e as alucinações que alguns de nós têm (em circunstâncias excepcionais) são testemunhas de que a realidade perspectivista dos objetos percebidos não é inatacável, não menos que a realidade também perspectivista - das entidades abstratas.

O (sub-)título desta seção evoca a célebre fórmula devida ao bispo Berkeley, aquele tipo de idealismo que Kant procurou refutar na primeira Crítica. Mas a semelhança já apontada entre o realismo perspectivista e a filosofia kantiana não é suficiente para descartarmos esse ponto de vista do idealismo absoluto. Pois para decidirmos se ser é ou não ser percebido, devemos primeiro saber o que é ser percebido. Nem tudo o que se percebe realmente é e, por outro lado, junto com Kant devemos admitir que pode haver realidades que não percebemos, realidades não perceptíveis no sentido usual do termo, isto é, percepções sensoriais. 


\section{A realidade perspectivista dos objetos abstratos}

Se pressupusermos que os objetos abstratos são criações nossas, sua realidade só pode ser perspectivista. Isso não quer dizer, como veremos adiante, que sejam criações nossas os objetos das percepções externas ou sensoriais, aquelas percepções que os empiristas modernos, como Hume, denominavam impressões dos sentidos. Elas são, certamente, resultado de interações entre nosso aparato sensorial, no qual estão incluídas certas capacidades neurofisiológicas nossas, e determinados elementos ambientais. Mas esse é o ponto que devemos discutir adiante mais detalhadamente. Por outro lado, tomando uma postura plantonista mínima, no sentido de que os objetos culturais são abstratos e existem fora do espaço e do tempo, o fato de que os objetos culturais - e, a nosso ver, todos os objetos abstratos - serem construções nossas não implica que nós os produzamos de maneira deliberada, nem que tenhamos sobre eles controle ou, se quisermos, controle suficiente. ${ }^{6}$ Esse é um ponto sobre o qual Popper (1972) insiste em sua discussão a respeito da natureza do Mundo 3.

É claro que alguns objetos ou realidades culturais podem ser criados deliberadamente por alguns seres humanos. Mas isso não os coloca sob o controle total (e, frequentemente, nem mesmo parcial) de seus criadores. Dois ou mais indivíduos podem decidir fundar um clube ou, quem sabe, uma sociedade filosófica. Mas esse clube filosófico, se vingar, como se diz popularmente, se vier a existir no sentido de possuir poder normativo sobre o comportamento de seus membros e, de algum modo, afetar seus estados mentais, depende de condições de base que não estão inteiramente sob o controle de seus fundadores nem de seus futuros membros. ${ }^{7}$ Os indivíduos pertencentes a tal clube filosófico (talvez, digamos, dos filósofos que defendem que há objetos abstratos) são parte das condições de base da existência (isto é, emergência) do clube, da realidade abstrata que ele é. Ora, já que o reconhecimento da própria existência de tal clube e do que ele representa depende de saber determinado dialeto filosófico (aquele derivado do platonismo e refinado pela filosofia subsequente), essa língua filosófica é outra das condições de base de tal clube. Ao saber a língua e, em princípio, poder vir a ser um membro de tal clube é que alguém pode reconhecer sua existência no mundo. A realidade desse clube, o reconhecimento de sua existência, isso depende de se estar colocado na perspectiva apropriada. Por isso sua existência é perspectivista. Mas esse clube será real — e não mera ficção — se realmente houver pessoas que a ele pertençam e cujo comportamento seja afetado pelo fato de pertencerem a ele. E, por outro lado, é real apenas de forma perspectivista. Ele será completamente ignorado por aqueles que não souberem a língua e não souberem que pode haver um clube filosófico platonista no mundo.

É claro que estamos simplificando e que as condições culturais de base da existência de tal clube filosófico são mais amplas e envolvem diversos elementos culturais que não estamos mencionando. Mas acreditamos que a ideia básica está clara. Em

Principia 21(2): 251-289 (2017). 
suma, as realidades culturais - abstratas que são — só podem ser reconhecidas por aqueles que possuem as condições de base apropriadas. Trata-se, pois, de um caso similar à visão das cores. Para ver determinadas cores, precisamos possuir as condições de base apropriadas. Mas uma vez vistas por nós, as cores que vemos são inevitáveis. O mesmo se dá no caso das realidades abstratas, incluídas nessa classe todos os objetos culturais, obviamente, porque para o tipo de platonismo mitigado que adotamos, todas as realidades abstratas são culturais. Elas nascem e vivem apenas de forma perspectivista.

No mundo social, costumes, valores e normas de diversos tipos são coisas tão impositivas quanto as paredes da sala em que nos encontramos. A metáfora das paredes sugere que tais realidades sociais limitam nossa ação. Mais do que limitar nossa ação, elas a modulam. Pensemos então no piso da sala, que também nos limita. Os costumes, valores e normas sociais também são nosso chão. Essa metáfora, por sua vez, sugere que as mesmas realidades sociais permitem nossa ação. Chamemos essas condições sociais todas - que limitam, mas também possibilitam a ação — de fatores ou condições determinantes, ou ainda condicionantes. As condições de base de qualquer tipo de realidade no mundo são pelo menos parte de suas condições determinantes. A ação humana em sociedade tem dentre suas condições de base uma pluralidade de objetos culturais, como normas de diversos tipos, costumes, valores, práticas comuns etc., e a própria linguagem verbal ou simbólica que possibilita tudo isso.

De uma perspectiva reducionista, as condições de base de uma realidade são todas as suas condições determinantes. Da perspectiva emergentista, as condições de base de certa realidade são apenas parte de suas condições determinantes; e essas últimas podem incluir também a própria economia geral do sistema emergente em questão e as relações dele com outras realidades. Falando então da ação humana, suas condições determinantes incluem as condições de base internas e externas (como o aparato neurofisiológico dos sujeitos humanos e a realidade social na qual eles estão inseridos) e o próprio contexto no qual eles agem, contexto que inclui outros sujeitos e o que eles fazem.

A percepção desse contexto é algo que se dá apenas para aqueles que estão posicionados adequadamente e, do mesmo modo, que estão equipados adequadamente. Falemos então das condições determinantes da percepção de uma realidade abstrata, tal como uma realidade social ou cultural qualquer. Na medida em que a percepção das realidades culturais requer que o indivíduo possua determinados conceitos, valores etc., temos aqui o caso em que no sentido próprio podemos falar de pertencer a determinada comunidade epistêmica. É quando, metaforicamente, dizemos que o indivíduo vê o mundo da perspectiva de sua comunidade. A expressão "visão de mundo" tem sido tradicionalmente empregada para esse caso, como sabemos.

Isso tudo é conhecido, mas nosso ponto aqui é argumentar que se trata também de um processo perceptivo, similar àquele da visão das cores. A diferença, contudo, 
é que o aparato cognitivo necessário para perceber certas realidades culturais inclui elementos de outra natureza, digamos. A percepção de certas cores requer olhos e cérebro de determinada comunidade cromática. E a percepção de certas realidades culturais requer conceitos e valores de determinada comunidade epistêmica. O termo "percepção", nesse caso, não está sendo empregado metaforicamente, embora seja em analogia com a percepção das cores. Nós não inferimos, nem simplesmente pensamos as realidades culturais; nós as percebemos. E, percebendo-as, nós também as conhecemos, descobrimos características suas das quais não estávamos cientes. Lembremos o caso da saudação entre dois indivíduos. Percebemos a saudação e podemos descrevê-la. Podemos, por exemplo, dizer que eles se saudaram efusivamente, ou discretamente etc.

Aqui avançamos o ponto sobre o qual devemos argumentar. E a objeção que se pode levantar é que aquilo que só pode existir de determinada perspectiva, e relativamente a ela apenas, não pode ser algo real, nem objeto de percepção, portanto, mas apenas de inferência; só pode ser um objeto de pensamento. Vamos lidar com essa dificuldade na próxima seção. Mas voltemos um instante para aquelas realidades abstratas que não consideraríamos de caráter social, embora possamos admitir que as realidades sociais ou culturais sejam abstratas no sentido acima especificado. As realidades a que nos referimos, que seriam abstratas mas não culturais, são as entidades matemáticas.

Se as classes, as figuras geométricas, os números etc. são objetos abstratos, apesar dos argumentos dos intuicionistas, dificilmente os consideraríamos criações nossas, como os demais objetos do Mundo 3 de que Popper fala. Independentemente disso, contudo, que constitui o objeto de toda uma filosofia da matemática, de qualquer forma, à primeira vista, parece que tais objetos matemáticos não são objetos de percepção. O triângulo que vemos impresso numa folha de papel não possui as exatas propriedades que os triângulos planos da geometria euclidiana possuem, como ter os ângulos internos somando $180^{\circ}$. O triângulo que pode ser percebido, porque pode ser visto por nós, diríamos, é apenas um modelo concreto do triângulo ideal, do triângulo abstrato que, esse sim, possui as propriedades euclidianas conhecidas. Se passarmos então para os números, fica claro que nem mesmo esse tipo de engano seria possível. Quaisquer representações concretas de um número são, claramente, outra coisa, diferente do próprio número. "Dois", ou "2", ou "II" etc. não são nem mesmo modelos pictóricos do número dois. Assim como "triângulo" e " $\Delta$ " para com um triângulo, aquelas representações do número dois são apenas símbolos convencionalmente utilizados para representar a entidade abstrata. Logo, percebemos o símbolo ou o modelo pictórico, se for o caso, mas não o objeto abstrato. E por isso mesmo Platão tomou essas entidades como típicos habitantes do mundo das Formas eternas.

Assim, em analogia com esse caso, se considerarmos os objetos culturais realidades abstratas, se eles fazem parte do mesmo Mundo 3 de Popper, então nenhum deles 
pode ser objeto de percepção, mas apenas de pensamento. Bem, estamos cientes de que o caso das entidades matemáticas representa uma dificuldade maior para nossa perspectiva do que aquele das realidades culturais. Mas se pudermos mostrar que as realidades culturais são realmente percebidas e não inferidas, então estaremos a meio caminho de mostrar que todas as realidades abstratas são objetos de percepção.

\section{Percebemos com o cérebro?}

A neurofisiologia tem mostrado que não vemos com os olhos apenas e que, de fato, o que vemos não pode ser aquilo que está projetado na retina, por exemplo. Esse é, de fato, um caso simples e, por assim dizer, já desvendado pela ciência contemporânea da visão. Na retina está projetada uma imagem invertida e curva (distorcida, portanto), daquilo que vemos, da imagem de que temos consciência, que pode ser, por exemplo, um cubo com arestas perfeitamente retas. Essa imagem - que é aquilo que podemos dizer que vemos mesmo - é uma construção que requer determinado processamento, digamos assim, a partir da informação que o nervo óptico e outros caminhos neuronais no cérebro conduzem até o córtex visual. ${ }^{8} \mathrm{O}$ mesmo vale, obviamente, mutatis mutandis, para os outros quatro sentidos. Mas fiquemos com a visão, que tem tido desde os gregos clássicos esse enorme apelo filosófico. O cubo que um de nós vê diante de si, como se fosse um sólido perfeito, um objeto geométrico de três dimensões, é apenas, por assim dizer, um constructo retino-cortical a partir de determinada estimulação recebida por meio de um processo físico, especificamente óptico, envolvendo a luz do tipo que incide na superfície de nosso planeta e o suposto - cubo sólido, extenso e impenetrável, o objeto material que cremos estar sendo percebido por um de nós logo ali à sua frente sobre a mesa. Esse objeto é percebido por nosso cérebro tanto quanto por nossos olhos; ou, melhor dizendo, nós o percebemos através dos dois processos: o físico, que envolve a luz e as superfícies do objeto material, e o neurofisiológico, que vai da retina ao córtex visual e às áreas corticais ligadas à consciência.

De fato, esse cubo da percepção não é apenas um constructo retino-cortical apresentado à consciência de um de nós. Ter consciência de ver o cubo requer a atividade de outras áreas do cérebro, de tal forma que um sujeito humano possa se dar conta de ver um cubo à sua frente. A neurofisiologia cognitiva contemporânea pode nos oferecer os detalhes, dos quais podemos nos passar aqui. Mas devemos aceitar que o cubo da percepção envolve também o conceito de cubo, mesmo que não envolva o termo "cubo", por mais que tal conceito possa parecer algo obscuro se o separamos da palavra que o denota. Esse conceito de cubo é o conceito de um sólido, um sólido é um corpo, um corpo é feito de matéria, e assim por diante. Não é difícil percebermos o quanto de conceitual - ou cognitivo, nesse sentido específico - está envolvido na 
percepção do cubo. E é claro que isso nos faz lembrar mais uma vez de Kant.

Contudo, a epistemologia de viés empirista — antes e depois de Kant — se esforçou muito para traçar uma fronteira nítida entre o percebido e o pensado. E parece que estamos aqui borrando essa linha demarcatória e querendo colocar nosso cubo bem sobre ela, com uma parte que depende dos olhos, uma parte que depende do pensamento, e uma parte intermediária e confusa que depende do cérebro e de possíveis realidades psíquicas (cognitivas). E, afinal, por que unir aquilo que a tanto custo já fomos capazes de separar — pelo menos conceitualmente —, mostrando que perceber é uma operação ou processo cognitivo de um tipo diferente de pensar? Se concedermos que perceber é um processo cognitivo, já estamos concedendo tudo o que é preciso. Pois o empirista mais radical argumentaria que perceber não tem nada de cognitivo, mas apenas de ... De quê? É difícil preencher a lacuna com algo que seja unicamente físico sem cair em um tipo muito ingênuo de realismo fisicalista.

Para não parecer que estamos, por outro lado, apenas defendendo algum tipo ingênuo e tolo de relativismo que generaliza a partir de resultados da neurofisiologia cognitiva, pensemos em termos evolutivos. Os indivíduos que veem cubos à sua frente são membros de uma espécie que evoluiu neste planeta tendo seus olhos e seus cérebros adaptados às condições ambientais de tal modo a verem o que é preciso para eles ver, digamos assim, para que eles sobrevivam. Isso também tem sido lugar comum entre os filósofos. Mas é menos comum argumentar que, nesse processo evolutivo, também entram aspectos culturais. Também muito se fez na filosofia do passado para separar a cultura da natureza, assim como se fez para separar a percepção do pensamento. Ou seja, vemos o que é preciso ver não apenas em virtude da confluência entre condições determinantes neurofisiológicas e ambientais, naturais ou físicas, digamos, mas também em virtude da confluência de condições neurofisiológicas e cognitivas com condições determinantes ambientais do tipo cultural ou social. ${ }^{9}$

De fato, não vemos com o cérebro (ou, mais precisamente, com o córtex visual, se quisermos dizer assim), mas percebemos alguma coisa graças aos olhos e ao cérebro que temos, além dos conceitos que temos. Quem percebe é o indivíduo humano intacto, cujo aparato cognitivo tem de possuir pelo menos essas três ordens de condições de base: olhos, cérebro e conceitos visuais. O que vemos é o cubo, e não um objeto material que interpretamos como cubo. Esse tem sido outro aspecto salientado pelos filósofos que defendem a chamada contaminação da observação pela teoria. E uma vez que o termo "contaminação" tem uma carga semântica um tanto pejorativa, alguns preferem falar da dependência da observação em relação à teoria e seus conceitos. ${ }^{10}$ Mas essa dependência precisa ser sustentada apenas quando pressupomos juntamente com a filosofia mais tradicional que teoria e observação são duas coisas separadas, distintas, resultados de dois processos que, na melhor das hipóteses, podem convergir, e não como duas etapas do mesmo processo.

Principia 21(2): 251-289 (2017). 
Por isso mesmo não faria sentido, tendo em conta os resultados da neurofisiologia dos sentidos, como no caso da visão, querermos argumentar que vemos com nossos cérebros, em vez de nossos olhos. Vemos graças a esses elementos de base da visão, entre outros. Percebemos graças à totalidade do aparato perceptivo. Logo, o que é percebido não está lá no mundo e em si, como podemos dizer seguindo Kant mais uma vez. O que é percebido por nós emerge das condições de base ao mesmo tempo neurofisiológicas e cognitivas, de um lado, e ambientais, de outro.

Nosso realismo de senso comum sobre os corpos materiais - realismo esse, aliás, com o qual não achamos que haja nada de errado enquanto ele se abstiver que afetar nossas teorias mais elaboradas —, contudo, sugere que esses objetos estão ali, no mundo, naquilo que são em si, independentemente das perspectivas adotadas para percebê-los. Ora, desde Kant até a atual neurofisiologia da percepção temos os reiterados resultados que afirmam que não é assim. Mas esse realismo de senso comum é para nós uma espécie de segunda natureza que nos impede de entendermos que toda percepção é perspectivista. Como resultado da ação desse realismo, é mais difícil percebermos o caráter perspectivista da percepção de corpos. E, justamente, os objetos abstratos devidamente analisados nos permitem entender que a percepção é sempre perspectivista. O único problema é, como dissemos de início, que as análises tradicionais não tomam os objetos abstratos como objetos de percepção. Todavia, vamos tentar esse caminho.

\title{
4. Barras e paredes morais
}

Em uma célebre passagem de sua Investigação sobre o entendimento humano, ao tratar das noções tradicionais de liberdade e de necessidade, Hume diz o seguinte:

\begin{abstract}
Um prisioneiro que não tem nem dinheiro, nem recursos, descobre a impossibilidade de escapar tanto quanto ao considerar a obstinação de seu carcereiro como ao considerar as paredes e barras que o rodeiam; e, em todas as suas tentativas de se libertar, escolhe antes trabalhar sobre a pedra e o ferro de uma coisa do que sobre a natureza inflexível da outra. (Hume 2007 [1777], p.65s; seção VIII, 19.)
\end{abstract}

Dissemos acima que é real aquilo que não podemos evitar, aquilo que se nos apresenta como inevitável. É conhecida a posição de Hume sobre as realidades morais como algo tão inevitável quanto as realidades físicas, posição que está tão bem expressa na citação acima. De fato, o aspecto mais saliente da posição de Hume consiste em considerar nossas amarras morais como mais fortes que as amarras físicas - e por isso mesmo é sobre essas últimas que o prisioneiro razoável vai procurar agir em sua busca de liberdade. A questão então, para voltarmos a ela, é: o prisioneiro percebe ou infere a determinação de seu carcereiro? Ele certamente, segundo o

Principia 21(2): 251-289 (2017). 
próprio Hume, percebe as paredes e as barras da prisão. Hume diz apenas, contudo, que ele considera ("considers the obstinacy of the gaoler..."); não diz que o prisioneiro percebe essa obstinação. Mas o que é, então, que ele percebe e que o leva a considerar real tal obstinação do carcereiro, real e mais forte que o ferro e a pedra?

Vindo em socorro da epistemologia tradicional e de Hume, Carnap (1967), por exemplo, nos diria que o prisioneiro percebe o comportamento do carcereiro. Mas, pensando bem, consideraria o próprio Carnap, já que o comportamento são os movimentos do corpo do carcereiro e suas relações com outros elementos ambientais, outros corpos, o que o prisioneiro realmente perceberia seriam as relações entre tais corpos, entre eles o corpo do carcereiro. Portanto, o próprio comportamento do carcereiro é inferido, e não percebido. Mas há algo de muito mal contado nesse relato. Pois as relações de movimento entre determinados corpos (entre eles aquele do carcereiro) não podem ser percebidas, já que são abstratas, pois esse é um dos pressupostos da análise. Do ponto de vista do solipsismo metodológico adotado por Carnap, os objetos de percepção são apenas as vivências elementares (Erlebnisse) ou, como a epistemologia desde Russell tem dito, os dados dos sentidos. Ora, as relações não estão dadas aos sentidos, como nos ajudaria a afirmar o próprio Hume — aqui socorrido por Carnap.

Todavia, para o esquema adotado por esses autores, isso não faria diferença, pois a partir de seus dados dos sentidos, de suas impressões sensíveis, o prisioneiro poderia inferir de qualquer forma a obstinação do carcereiro. E como ele pode testar essa hipótese reiteradamente, ele considera essa obstinação uma realidade moral, isto é, não física. Ela é uma realidade ao mesmo tempo psíquica e cultural, obviamente. Ela é uma realidade social, uma vez que o carcereiro está cumprindo um papel social. Sua obstinação é, por assim dizer, ex officio. E, nesse caso, ela é, de fato, uma realidade abstrata, já que é social. A obstinação do carcereiro é uma das formas pelas quais ele participa do Mundo 3.

A questão que precisamos levantar então é o que permitiria ao prisioneiro solipsista de Hume e Carnap inferir a realidade dessa obstinação do carcereiro. No sistema construcional de Carnap (1967, §40) há a noção de formas de ascensão (Stufenformen). Segundo Carnap, trata-se de uma definição por uso; isto é, uma função proposicional para um novo símbolo é satisfeita pelos mesmos objetos que satisfazem uma função com antigos símbolos, sendo, portanto, essas funções coextensivas. Em termos mais simples, o prisioneiro pode falar da obstinação do carcereiro porque ele, implicitamente (no uso), define "obstinação" por meio de uma função proposicional como, por exemplo, " $x$ é obstinado" tomada como coextensiva com uma função do tipo “ $x$ se movimenta assim, assim...". Ora, é óbvio que está faltando aqui o conceito que permite considerar essas duas funções proposicionais como coextensivas. $\mathrm{Ou}$, em termos mais simples ainda: falta um conceito que permita equiparar certos movimentos com um traço moral.

Principia 21(2): 251-289 (2017). 
Como, ao contrário de um racionalista, para o empirista radical, esse conceito tem de provir ou da experiência passada ou, no caso, mais precisamente, da experiência passada de utilizar dois termos díspares - um do vocabulário mentalista, outro do vocabulário fisicalista - como coextensivos, ou a definição é puramente arbitrária, ou ela está baseada em determinadas percepções.

Uma saída a essa altura seria dizer que se trata de uma percepção interna, que percebemos que fazemos a conexão dos dois conceitos, do conceito de obstinação com certos conceitos comportamentais ou puramente fisicalistas. Mas isso, mais uma vez, não resolveria o problema, pois temos então de perguntar por aquilo que permite fazer a conexão que percebemos interna e mentalmente. Ora, sabemos que Kant tem uma solução elaborada para isso, mas o empirista não está disposto a pagar o preço da filosofia transcendental.

O sistema construcional desenvolvido por Carnap em seu Aufbau, que citamos acima, é dos anos 1920s e, como é conhecido, na década seguinte, Carnap abriu mão do solipsismo metodológico e do fenomenalismo daquela obra e passou a defender que a linguagem fisicalista era mais adequada para a análise que ele desejava empreender, por já ser uma linguagem universal (Carnap 1995 [1934], p.67s). No modo material do discurso, tal como o próprio autor também coloca essas questões, isso significava que os objetos físicos (e não mais os objetos autopsicológicos) constituiriam a base do sistema da ciência unificada.

É claro, então, que como Carnap coloca o problema simplesmente como aquele de adotar uma forma de linguagem para fazer a reconstrução racional das cognições, essa abordagem não parece de muita valia para o que desejamos discutir aqui. Mas mencionamos o assunto para deixar claro, de nossa parte, que não se trata de simplesmente redefinirmos o verbo "perceber", nem o substantivo "percepção" e de utilizarmos esse artifício semântico para podermos sustentar que percebemos objetos abstratos do mesmo modo que percebemos (sem qualquer ênfase) objetos físicos. De fato, por mais que as análises de Carnap em suas duas fases (a fenomenalista e a fisicalista) sejam inadequadas para o que desejamos aqui, elas nos ajudam a ver que se (supostamente) não percebemos os objetos abstratos - como determinadas relações, como vimos no exemplo do prisioneiro, acima - , então também não percebemos objetos concretos - como, no mesmo exemplo, os movimentos dos corpos, entre eles o do carcereiro, cujo comportamento e cuja obstinação são inferidas pelo prisioneiro. Ora, tanto para Carnap, quanto para Russell, em cujas ideias sobre o imediatamente dado Carnap se baseia, o que percebemos são os dados dos sentidos, e tudo mais é inferido, como sabemos bem.

Além do aspecto meramente linguístico (ou semântico) antes mencionado, esse último ponto é o que faz com que esse tipo de análise seja completamente inadequado para nossos propósitos. Pois o que a neurofisiologia cognitiva nos revela hoje é que percebemos, sim, algo. O que vemos é o cubo diante de nós, por meio daqueles 
processos físicos e neurofisiológicos antes mencionados. Não vemos padrões de cor, brilho, saturação etc., como seria o caso dos supostos dados dos sentidos ou vivências elementares de que falam Russell e Carnap. Com base no que nos revelam as ciências da percepção, não estamos de modo algum dispostos a negar que percebamos corpos. A questão então seria: por que não podemos perceber algo mais?

Para voltarmos um instante a Hume, lembremos que ele se notabilizou na filosofia também - e talvez principalmente - por desafiar a ideia tradicional de relação causal. Não observamos essa relação entre as coisas, diz ele, como sabemos, mas apenas as próprias coisas - e somos levados pela natureza de nosso entendimento a supor que há uma relação entre elas. E se esse caso de objeto abstrato, que é tão básico no conhecimento do mundo, não se sustentaria como um caso de percepção externa, como poderia se sustentar o caso de relações que dizem respeito a realidades sociais? Lembremos que, naquela citação acima, Hume toma o cuidado de dizer que o prisioneiro considera - e não que ele percebe - a obstinação de seu carcereiro. Vimos também que a obstinação é uma realidade ao mesmo tempo psíquica e social; ela é uma forma de ser que depende de fatores psíquicos e, logo, neurofisiológicos, e de fatores sociais: culturais e morais. Assim, inferir a obstinação do carcereiro não é mais fácil do que percebê-la diretamente, já que tal inferência teria que estar baseada em outras percepções mais primitivas, em objetos que permitam fazer a conexão entre comportamentos e traços morais. Se a obstinação do carcereiro não é uma ficção, se ela é uma realidade moral, digamos, como sugere Hume, então ou ela é perceptível em si mesma, ou é inferida de outras realidades morais diretamente perceptíveis.

\section{Ficções úteis ou coisas-em-si?}

Uma forma alternativa de contornar o problema acima colocado seria aquela de considerar as realidades abstratas - todas elas, inclusive as realidade sociais - como ficções úteis. As capacidades físicas do mundo, entre elas nossas capacidades neurofisiológicas, seriam reais - e por isso poderíamos conservar a percepção dos corpos. E, assim, poderíamos continuar tranquilos com Hume. Outra forma, também conhecida, transitando de Hume para Kant, seria aquela de considerarmos as realidades abstratas como coisas-em-si. Elas seriam reais, mas inacessíveis, isto é, não perceptíveis. Mas se são reais, como admitiria Kant, elas podem ter influência sobre nós. Por isso seria legítimo inferi-las, mesmo que nos enganemos no detalhe sobre elas. Todavia, elas estariam lá, em seu mundo inacessível à percepção, agindo sobre nós. De fato, nesse caso, quanto às realidades morais, estaríamos tranquilos tanto com Kant quanto com Hume. Poderíamos dizer que o prisioneiro infere, por exemplo, a obstinação do carcereiro e a infere corretamente, embora ela não seja observável em si - e por isso mesmo decide agir sobre a pedra e o ferro. Mas tal obstinação está

Principia 21(2): 251-289 (2017). 
lá, inacessível à percepção, mas tão real e inevitável quanto as paredes da cela e as barras da grade. É como se nos chocássemos com um mundo de objetos a nossa volta sem que os possamos ver, tocar etc. Não sentiríamos de modo algum esses objetos, mas eles limitariam nossos movimentos. Numa ficção na mesma linha do Flatland de Abbott, ficaríamos por vezes imóveis sem sabermos o que nos imobiliza. Faltar-nos-ia outro sentido - talvez a intuição intelectual, que não temos, nos diria talvez Kant.

Já é uma grande batalha metafísica vencida se as entidades sociais e abstratas em geral forem consideradas reais, um mundo à parte, autônomo, tal como Popper concebe o Mundo 3. E como se não bastasse isso, pode-se ter aqui a impressão de que estamos querendo travar uma batalha tão difícil quanto a primeira, a saber, aquela a respeito do caráter observacional ou perceptível das realidades abstratas. Mas mesmo que a primeira dessas batalhas não seja considerada vencida, a segunda ainda pode ser travada. Pois se as realidades sociais e abstratas em geral não forem mais que ficções úteis redutíveis a realidades mentais, a estados subjetivos dos indivíduos humanos, essas próprias realidades psíquicas também são inobserváveis em si. Elas também estão fora do domínio da percepção para aqueles que desejam reservar o domínio do que é observável e perceptível apenas às realidades físicas. E como na percepção interna temos uma espécie de acesso direto a nossos estados psíquicos (pelo menos a uma parte deles), são esses reducionistas que teriam o ônus da prova de que nossos próprios estados mentais são apenas ficções úteis. Ora, nosso ponto é justamente aquele de equiparar a percepção das realidades abstratas àquela de outros tipos de realidades, tal como, em especial, as realidade psíquicas. Como sustentam fenomenalistas de diversos matizes, entre eles Carnap e Kant, cujas ideias mencionamos acima, mas também Berkeley e Russell, esses estados subjetivos da experiência vivida são as únicas realidades imediatas dadas. Portanto, se algo é real, elas são reais, antes de tudo.

Mesmo assim, quanto às realidades abstratas, parece que ficamos no mesmo dilema entre entidades inferidas ou ficções úteis. Há uma terceira possibilidade, mais curiosa, digamos, que é sugerida pelas próprias ciências da percepção hoje. A percepção dessas realidades poderia ser subliminar. Basicamente, isso quereria dizer que realmente percebemos as realidades sociais e abstratas em geral, mas não temos consciência do que percebemos. Não temos consciência de que as percebemos. Essa é uma possibilidade que pode nos revelar algo de interessante sobre a vida em sociedade e como nos movemos nela. A pesquisa sobre a percepção subliminar, que despertou algum interesse nas décadas de 1960 e 1970, ressurgiu ultimamente, e em obras como aquela de Leonard Mlodinow (2012), mostram resultados interessantes provindos da neurofisiologia. ${ }^{11}$ Esse autor comenta então o seguinte:

...para garantirmos nosso funcionamento adequado [smooth] tanto no mundo físico quanto no mundo social, a natureza dispôs que diversos processos de percepção, memória, atenção, aprendizagem e juízo sejam delegados a

Principia 21(2): 251-289 (2017). 
estruturas cerebrais fora da experiência consciente [conscious awareness]. (Mlodinow 2012, p.22.)

Gostaríamos de aproximar essa afirmação cientificamente fundamentada de Mlodinow com aquela — não cientificamente fundamentada, mas filosoficamente argumentada - de Quine em um de seus célebres artigos, "Espécies naturais", no qual ele afirma que possuímos um faro inato [innate flair] para identificar espécies naturais. (Quine 1969, p.114). Essa hipótese naturalista de Quine permite resolver, por exemplo, como ele faz no citado texto, o problema levantado por Goodman a respeito dos predicados projetáveis. A solução alternativa de Quine consiste então em afirmar que somos guiados por esse nosso faro inato (e do qual, obviamente, não temos consciência) na busca e na identificação correta das espécies naturais. Se Quine estiver certo, então, nos termos de Mlodinow, trata-se de um processo inconsciente de conhecimento, mas que tem de ser um processo de conhecimento fundamentado basicamente em um processo inconsciente de percepção. Ou seja, percebemos os contornos naturais do mundo mesmo que não tenhamos consciência de que os percebemos, pois o que fazemos - conscientemente - é agrupar determinados indivíduos em classes naturais. Mesmo que achemos que elas são arbitrárias, ficções úteis, digamos, elas não são. Elas são realidades naturais. Elas também não são meras realidades inferidas, realidades cuja existência será confirmada pelas ciências teoricamente elaboradas. Segundo Quine, que acredita que as ciências teoricamente maduras possam fazer isso e mesmo abandonar a noção observacional de espécie natural (e o que ele denomina a noção irredutível de similaridade), trata-se de um processo que começou lá em nossa natureza cognitiva puramente animal (p.137s).

$\mathrm{O}$ que acontece se aplicarmos ideias similares ao caso das realidades sociais? Do ponto de vista evolutivo, podemos também levantar a hipótese de que possuímos um faro inato para identificar realidades sociais. Nesse caso, essa identificação deve ser o resultado de um processo cognitivo que tem início em um processo especificamente de percepção. Ou seja, mesmo que inconscientemente, como sugere Mlodinow, percebemos os contornos do mundo social, assim como percebemos aqueles do mundo natural. Assim como no caso das realidades naturais (e não só as espécies), cujo conhecimento depende de certa elaboração linguística, por meio da criação de um vocabulário adequado (por exemplo, predicados fisicalistas), no caso do conhecimento de realidades sociais, que são abstratas — e, portanto, das realidades abstratas em geral —, também é necessária certa elaboração linguística. ${ }^{12}$

No aspecto estritamente linguístico, houve uma mudança importante no pensamento de Quine entre seus primeiros escritos e seus dois últimos livros, a saber: Pursuit of Truth e From Stimmulus to Science (Quine 1992; 1995, respectivamente). Nessas obras, ao contrário de seus escritos mais antigos, Quine afirma que ambas as linguagens fisicalista e mentalista são irredutíveis uma à outra. Ele abandona, as- 
sim, o ponto de vista reducionista segundo o qual todos os predicados não fisicalistas e intensionais (o que inclui o que é intencional, no sentido mentalista) devem ser reduzidos a predicados fisicalistas e extensionais. Ora a linguagem adequada para descrever diretamente as realidades abstratas, inclusive as sociais, é uma linguagem não fisicalista e intensional, tanto quanto a linguagem mentalista. Ela deve, portanto, também ser considerada irredutível e não eliminável se não estivermos dispostos a considerar as realidades abstratas como meras construções a partir de realidades psíquicas e físicas, tal como vimos no sistema construcional de Carnap para o caso dos objetos culturais.

Quine, por sua vez, não defende uma forma de realismo exatamente perspectivista, diríamos, mas aquele realismo associado a seu critério de compromisso ontológico. ${ }^{13}$ Se aceitarmos esse critério, ainda poderemos sustentar que as entidades abstratas são reais. Mas com isso, curiosa mas fundamentadamente por parte do autor, elas não perdem o caráter de ficções, uma vez que a relatividade ontológica impede que qualquer ontologia que seja possa possuir privilégios metafísicos em detrimento de outras. Ou seja, por exemplo, quando adotamos uma teoria física que trata de objetos macroscópicos (como a mecânica clássica), embora os corpos continuem a ser ficções ou entidades mitológicas — assim como os deuses de Homero —, são essas coisas que existem do ponto de vista da teoria adotada. E, assim, esse realismo não deixa de ser também perspectivista, ainda que a forma de perspectivismo que procuramos seja mais forte do que essa seria. Para esse perspectivismo mais robusto que consideramos, não há relatividade ontológica tal como Quine a concebe, pois a perspectiva em questão não é aquela de uma teoria entre outras, mas aquela da comunidade epistêmica como um todo. Logo esse perspectivismo mais robusto está muito mais próximo de Kant do que de Quine.

Todavia, como podemos fundamentar a ideia de que podemos defender a referência direta dos termos para entidades abstratas (inclusive as culturais ou sociais), encarando tais realidades como objetos de percepção e não de inferência ou de construção teórica? Voltemos então à noção de percepção inconsciente, acima mencionada.

A essa altura, uma objeção fundamental — e talvez bem fundamentada - que se pode levantar é que a noção de percepção inconsciente (da qual falam autores como Mlodinow) é a da percepção de coisas observáveis por nós com nossos sentidos sem ajuda: aquilo que é visível, audível etc. para os indivíduos correspondentes aos padrões perceptivos da comunidade epistêmica humana, ou seja, a grande maioria da população. E as entidades abstratas, entre elas as realidades sociais, não são observáveis de acordo com esse critério. Portanto, se elas são reais, não são acessíveis por meio da percepção, mas do pensamento, como já Platão sustentava. E, logo, elas continuam a ser entidades inferidas e não objetos de percepção.

Acreditamos que a esse respeito ainda é um autor como Quine que pode ser elu- 
cidativo e permitir fazer frente a tal objeção, preparando o caminho para considerarmos mais seriamente a hipótese de que as realidades abstratas são objeto de percepção inconsciente. Nos textos já mencionados sobre o compromisso ontológico e a relatividade ontológica, Quine coloca em pé de igualdade no que diz respeito a seu status ontológico todos os objetos, observáveis ou não de acordo com o critério de observabilidade apresentado no parágrafo anterior. São ficções úteis tanto os corpos macroscópicos, quanto as partículas microscópicas de que as teorias sobre a constituição da matéria falam, quanto ainda as entidades das quais as teorias matemáticas falam, como números e figuras geométricas. Ora, ainda que Quine não se refira às realidades sociais, é claro que também elas estão em pé de igualdade ontológica com os demais tipos de objetos, assim como, devemos reconhecer, os objetos psíquicos, como aqueles que estão supostamente em relação em nossos estados mentais no sentido comum da expressão. Se os corpos constituem uma espécie de ontologia de refúgio, como dissemos antes, isso se deve apenas a nossa natureza animal que, segundo Quine, nos torna aptos a identificá-los, assim como a identificarmos espécies naturais. Trata-se de nosso viés epistêmico, digamos, e não de nenhum privilégio ontológico desses objetos.

Há, portanto, também certo fenomenalismo na posição de Quine a esse respeito, pois, do ponto de vista cognitivo, todos esses objetos são construções. Trata-se do mesmo fenomenalismo que encontramos em Kant. A respeito desse último, diz Mlodinow (2012, cap.2), as pesquisas recentes em neurofisiologia e que empregam a nova noção de inconsciente convergem com a filosofia kantiana. E, assim, convergem também com aquela de Quine. Consubstanciarmos, contudo, a defesa do caráter perceptível das realidades abstratas, além das considerações já feitas em um quadro filosófico mais amplo (epistemológico e ontológico), como fizemos acima, requer também considerações empíricas sobre os processos perceptivos do ponto de vista neurofisiológico.

\section{A visão cega e outros mistérios da mente}

No capítulo 2 de seu livro, Mlodinow (2012) relata alguns casos curiosos estudados pela neurofisiologia das últimas décadas. Embora não se trate de uma obra filosófica, nem de uma obra de especialista em neurofisiologia cognitiva, mas de divulgação científica, o livro traz relatos interessantes quanto ao fato de que pelo menos grande parte de nossas decisões é resultado de conhecimento inconsciente e que tal conhecimento é elaborado a partir de processos de percepção que, por sua vez, também são inconscientes. Talvez o mais interessante deles seja aquele da visão cega (blindsight). Um caso de visão cega é quando um indivíduo nessa condição não tem consciência de ver um obstáculo, mas, mesmo assim, o evita. A explicação neurofisiológica é a

Principia 21(2): 251-289 (2017). 
de que o processo visual se dá; ele apenas não chega à consciência. O indivíduo não sabe por que evitou o obstáculo, obviamente. Mas sua visão inconsciente faz com que, também inconscientemente, ele aja de acordo com tal informação. ${ }^{14}$

Dado o ponto que desejamos defender, a analogia que imediatamente se sugere é que, do mesmo modo, percebemos realidades abstratas sem nos darmos conta disso. Não é exatamente isso, embora devamos reconhecer que tal analogia seria, de fato, atraente aqui. Ocorre, contudo, que uma condição como a visão cega costuma ser insuperável. E o que desejamos argumentar - e que está em conformidade com a experiência comum e o bom senso - é que a falta de percepção de realidades abstratas é uma condição que pode ser superada. Ora, isso, por sua vez, pode fazer pensar novamente na postura de Platão, para quem a cognição das realidades abstratas era resultado do trabalho da filosofia, como diz o sugestivo e conhecido Mito da Caverna. E, como já devemos ter deixado claro acima, não é também essa via aquela que desejamos escolher para trilhar na busca de solução do problema posto.

A referência a Platão traz de volta a velha objeção a toda forma de realismo quanto a realidades fora da experiência comum - para não dizermos realidades não perceptíveis, já que desejamos argumentar que tais realidades abstratas são perceptíveis de algum modo. Mas por estarem fora da experiência comum ou, mais precisamente, fora da experiência consciente da maioria de nós, as realidades abstratas são, naturalmente, objeto de dúvida. Em vez de coisas reais, elas podem ser apenas mitos ou ficções, como já dissemos. Mas as ficções não são necessariamente irrealidades. Podemos entender o termo "ficção" como denotativo de coisas que podem ou não ser reais, mas cuja realidade não está demonstrada. Nesse sentido, essa noção se aproxima daquela que Freud denominou ilusão em um de seus célebres textos sobre os fundamentos da civilização, a saber, "O futuro de uma ilusão" (Freud 1975).

Freud argumenta que a religião é uma ilusão e que uma ilusão não é a mesma coisa que um erro. Ele afirma que uma ilusão foi, por exemplo, aquela de Colombo quando chegou à América acreditando ter chegado às Índias. Como as ilusões derivam de nossos desejos, elas se aproximam das delusões (delusions). ${ }^{15}$ Tal como Freud (1975, p.30s) emprega essas noções, uma delusão é uma condição psiquiátrica, na qual o indivíduo percebe o que não existe. Mas, ao contrário, o que ele entende por ilusão é uma crença motivada por desejos que nos levam a desconsiderar certos aspectos da realidade. As delusões (entre elas, as alucinações) se são superáveis, o são graças a procedimentos terapêuticos. As ilusões podem ser superadas por simples contato continuado com a realidade, já que são, na verdade, no sentido de Freud, apenas crenças falsas. Mas, embora falsas, elas podem ser aproximadamente verdadeiras. Essa é a noção defendida pelo autor quanto à superação da ilusão da religião por meio do progresso do conhecimento (p.55). Uma ilusão pode então ser apenas uma aproximação menos adequada com relação à realidade, e que pode ser substituída por uma melhor aproximação. 
Como essa noção freudiana poderia ajudar em nossa discussão? Poder-se-ia dizer que a crença de alguns de nós (ou de alguns filósofos) em realidades abstratas é, de fato, uma delusão. Isso iria bem ao encontro do que acham alguns críticos do realismo platônico que pensam na postura defendida por Wittgenstein quanto a uma espécie de terapia que poderia nos livrar de mitos filosóficos e de senso comum. Mas como ficção ou ilusão no sentido de Freud, como aproximações da realidade, nossas crenças em entidades abstratas podem ter futuro, desde que, de algum modo, esclarecidas. Para a discussão que estamos empreendendo, inclusive tendo em conta os comentários que já fizemos a respeito do naturalismo de Quine, o texto de Freud que citamos é um tanto surpreendente. A respeito das ilusões justamente e da alegação de alguns de que a natureza das coisas sempre permanecerá para nós inacessível, porque nosso conhecimento está limitado por nosso aparato cognitivo (o que faz lembrar, obviamente, Kant), Freud diz o seguinte a respeito da relação entre esse nosso aparato e o mundo que ele deve nos permitir conhecer:

Em primeiro lugar, nossa organização - isto é, nosso aparato mental foi desenvolvido precisamente na tentativa de explorar o mundo externo e, portanto, ele deve ter realizado em sua estrutura algum grau de adequação; em segundo lugar, ele mesmo é uma parte constitutiva do mundo que procuramos investigar, e ele se dispõe a tal investigação; em terceiro lugar, a tarefa da ciência será completamente realizada se a limitarmos a mostrar como o mundo deve aparecer para nós em consequência do caráter particular de nossa organização; em quarto lugar, as descobertas últimas da ciência, precisamente em virtude da forma pela qual elas são alcançadas, são determinadas não apenas por nossa organização, mas pelas coisas que afetaram tal organização; finalmente, o problema da natureza do mundo que não diga respeito a nosso aparato mental perceptivo é uma abstração vazia, destituída de interesse prático. (Freud 1975, pp.55-6.)

Temos aí uma versão resumida de um naturalismo perspectivista, com claro teor evolucionista, de viés darwinista, e que ecoa também pontos das posturas de Kant e de Quine. O mais importante - e que, por assim dizer, está nas entrelinhas do texto de Freud - é que ele não está se referindo apenas a nosso conhecimento de realidades naturais, digamos, mas de realidades sociais. Ele está discutindo o papel de uma delas, a religião, na constituição e manutenção da sociedade e na necessidade de superar tal realidade social, que ele compara às neuroses infantis, por meio de um conhecimento mais adequado da sociedade e da psique humana.

Voltando então ao caso da visão cega, antes mencionada, o que queremos sugerir é que podemos instintivamente pautar nosso comportamento com base na percepção de realidades sociais das quais não temos consciência. Mas essa condição é superável, e como argumentaria Freud a essa altura, podemos chegar a tomar consciência de que percebemos certas realidades sociais. Podemos trazer à consciência essa percepção de uma parte das realidades abstratas.

Principia 21(2): 251-289 (2017). 
Poder-se-ia dizer, contudo, a essa altura, que o termo "percepção" se reserva para processos conscientes, ou talvez para produtos na consciência de determinados processos. Nesse caso, não haveria percepções inconscientes, como a discussão acima sugere, mas apenas percepções conscientes; a própria expressão "percepção consciente" seria um pleonasmo vicioso e a expressão "percepção inconsciente" seria uma contradição em termos. Isso faz lembrar a noção sustentada por Locke de que nossas ideias são aquilo que está presente ao entendimento; e, portanto, não poderia haver ideias das quais não temos consciência - presumindo, como é o caso nesse autor, que o entendimento é completamente consciente.

Contudo, ir por esse caminho seria apenas transformar o caso em uma disputa por palavras e seria fugir do problema, já que o que está em questão, afinal, seja lá qual for o termo utilizado, é se uma informação provinda do ambiente, mesmo que não atinja a consciência, pode provocar determinadas respostas apropriadas do sujeito, como no caso da visão cega. Nesse caso, não parece nem um pouco inapropriado aplicar o termo "percepção" para aquela etapa do processo na qual a informação, por assim dizer, instrui o sujeito de tal forma que ele aja de uma maneira particular, como no caso do roubo do relógio de Peirce.

Por outro lado, um caso como esse da visão cega, mesmo que aceitemos que ele ilustra a noção de percepção inconsciente, permite levantar uma objeção mais séria, a saber: na percepção inconsciente (na visão cega, por exemplo), o sujeito percebe algo que está lá; e, aparentemente, ao contrário, no caso de realidades abstratas, pode não haver nada para ser percebido. É nesse ponto que nossa discussão deve se concentrar, afinal!

\section{A percepção de padrões mentais}

Apesar dos argumentos até aqui reunidos, ainda se poderia argumentar que as realidades sociais, que são uma parte das realidades abstratas, são apenas inferidas, tal como a última observação da seção anterior deixa claro. Assim, as realidades sociais seriam conhecidas apenas por seus efeitos, a saber, por seu efeito normativo no comportamento humano, assim como, por exemplo, os fótons (que são certamente inobserváveis e não são de forma alguma objetos de percepção) são considerados reais em virtude de seus efeitos sobre nossos olhos.

Se as realidades sociais não são perceptíveis, o conhecimento que temos delas é similar àquele que temos das outras mentes — e diferente do conhecimento que temos dos fótons. Inferimos esses últimos com o auxílio de uma teoria bem articulada com experimentos, uma teoria que fala de uma realidade física microscópica, de algo concreto, embora fora do âmbito de nossas capacidades perceptivas. Inferimos outras mentes a partir do comportamento manifesto e independentemente de teorias. $\mathrm{E}$

Principia 21(2): 251-289 (2017). 
não percebemos as mentes dos outros seres humanos não porque elas estejam fora do âmbito de nossas capacidades perceptivas, mas porque elas, em princípio, são coisas inobserváveis. Não há condições físicas possíveis que as tornem observáveis. Do mesmo modo, inferimos a presença de uma instituição, uma realidade abstrata, social, a partir do comportamento manifesto dos indivíduos que a ela pertencem. Essa seria a concepção comum a respeito desses pontos.

A nosso ver, contudo, tanto a percepção social quanto a percepção mental estão mal caracterizadas dessa forma que é, afinal, aquela que Carnap adotou em seu sistema do Aufbau. A percepção mental e a percepção social são realidades cognitivas, e não ficções ou ilusões (no sentido freudiano), isto é, inferências tomadas como se fossem conhecimento direto. Além disso, por mais que a ciência atual sugira fortemente essa noção, a distinção entre a inobservabilidade contingente dos fótons e a inobservabilidade necessária das mentes e das instituições não é inatacável. Trata-se, como sabemos, da mesma demarcação entre coisas em si observáveis e coisas em si não observáveis, como as discussões de décadas atrás sobre o realismo científico teve em consideração. Trata-se, enfim, da mesma demarcação sustentada por alguns entre experiência (e percepção, e observação), de um lado, e teoria (e inferência, e conhecimento proposicional), de outro, demarcação também tão contestada por tantos, entre eles Dennett. ${ }^{16}$ Trata-se da própria demarcação que estamos também questionando.

A nosso ver, é tão difícil (filosoficamente) sustentar que há uma separação nítida entre percepção e pensamento (ou, se quisermos, em outros termos: entre observação e teoria), enquanto diferentes processos psíquicos (ou mentais, se quisermos) quanto sustentar que há uma continuidade entre as duas coisas, enquanto dois momentos diferentes do mesmo processo cognitivo, uma ideia com a qual simpatizamos, devemos enfatizar, e que é defendida por Dennett no texto citado. Mas, segundo o autor, sustentar uma posição filosófica a esse respeito é o que é preciso fazer, já que as disciplinas empíricas, mesmo que nos forneçam dados interessantes, não são capazes de decidir a questão.

Essa questão mais geral não é a única discutida por Dennett, que também examina uma questão específica igualmente polêmica e que tem relação mais estreita com a discussão que estamos empreendendo aqui. Dennett se diz um realista a respeito de crenças (e opiniões, e outras entidades mentais) e considera as crenças que atribuímos a um sujeito humano, quando adotamos a abordagem intencional, objetos abstratos (Dennett 1991, p.29). As crenças são reais e abstratas, diz Dennett, assim como, por exemplo, centros de gravidade. Mas, de seu ponto de vista, também elétrons e determinados padrões (patterns) são reais. Referindo-se à Atitude Ontológica Natural (NOA, Natural Ontological Attitude) proposta por Arthur Fine, que Dennett também se propõe a adotar a respeito de tais entidades, ele diz o seguinte:

Principia 21(2): 251-289 (2017). 
[...] vamos dizer que as crenças e outros estados mentais são tão reais quanto elétrons e centros de gravidade. Desejamos mostrar que um realismo mitigado [mild realism] é a doutrina que faz mais sentido quando devemos falar de padrões reais, tais como os padrões reais discerníveis a partir da abordagem intencional. (Dennett 1991, pp.30-31; itálicos no original.)

Esses padrões reais que podemos identificar por meio da abordagem intencional são, por exemplo, comportamentos e os correlativos estados mentais, tal como a própria psicologia popular [folk psychology] presume haver. Esses padrões, assim como outros, mais simples, como padrões visuais, alguns dos quais Dennett examina em seu citado artigo, são percebidos por nós, embora essa percepção dependa de nosso aparato perceptivo/cognitivo. Nossa percepção dos padrões depende não apenas de nossos órgãos dos sentidos, diz Dennett, mas também de nossos próprios interesses. Ele diz:

Outras criaturas, com diferentes órgãos dos sentidos, ou diferentes interesses, poderiam perceber prontamente padrões que sejam imperceptíveis para nós. Os padrões estariam lá o tempo todo, mas apenas eles seriam invisíveis para nós. (Dennett 1991, p.34; itálicos no original.)

Esse comentário lembra nossa discussão anterior a respeito da visão das cores, vale notarmos. Ora, essa passagem, embora descontextualizando-a um pouco (mas apenas um pouco, como veremos a seguir com os comentários de Davidson), vem bem ao encontro do que desejamos defender, que é que as realidades sociais (abstratas que são) podem ser percebidas por quem esteja cognitivamente aparelhado para tanto, assim como perceber certos padrões e certas cores depende de estar aparelhado para tanto. A ideia de Dennett que vem ao encontro da nossa é, de fato, que, mesmo sendo abstratos, os padrões são realidades perceptíveis. E é isso o que, atendo-se a um fisicalismo mais robusto, Davidson critica. Ele diz:

A ideia de Dennett é que o que é real é o comportamento, e os estados intencionais são padrões nesse comportamento. Os padrões não são definidos em termos do comportamento - eles são percebidos por um observador quando esse toma a "perspectiva intencional". O valor dos padrões é que eles reduzem uma situação física ampla, para nós incrivelmente complexa, a algo que possamos apreender, alguma coisa com base na qual possamos fazer predições aproximadas. Os padrões são em um (reduzido) sentido reais, embora abstratos; e diferentes pessoas podem perceber diferentes padrões no mesmo campo comportamental. Alguns desses padrões podem ser mais úteis para predizer e entender alguns fenômenos; outros, para outros fenômenos. Todos esses padrões são "reais", mas quando eles são diferentes, não se pode dizer que eles representem as reais atitudes do agente em questão.

$[\ldots]$

Principia 21(2): 251-289 (2017). 
Dennett nos diz que os padrões são abstrações, como os centros de gravidade. Mas, então, podem eles ser crenças e desejos? Crenças e desejos, gostamos de pensar, são estados de um corpo físico que podem ter consequências causais; presumimos que as abstrações não têm relações causais. As forças não agem sobre os centros de gravidade, mas sobre as coisas que possuem centros de gravidade; e as forças certamente alteram nossas crenças e intenções. Percebemos padrões? Parece-nos que não: o que percebemos é algo que tem certo padrão e, com sorte (e na adequada perspectiva), podemos perceber que essa coisa tem esse padrão. Assim, a questão não é se os padrões são reais. Sendo nominalistas, pensamos que os padrões, assim como as figuras e os números, são tão reais quanto possam ser. Mas não vemos como as atitudes proposicionais de uma pessoa possam ser padrões. Se perguntarmos o que exibe o padrão, podemos dizer que é a pessoa, ou podemos dizer que é o comportamento observável da pessoa. Mas em nenhum caso não está em questão o status ontológico das atitudes [proposicionais]. (Davidson 2001, pp.81-2; itálicos no original.)

Ainda que tão longa, essa passagem é importante para, de um lado, enfatizar a compreensão que Dennett tem do assunto e, de outro, deixar claro o tópico principal da crítica feita por Davidson. No que diz respeito a nossa discussão sobre a percepção, a posição de Davidson é que o que observamos ou percebemos são coisas e pessoas — e então percebemos que essas coisas e pessoas possuem determinado padrão. Mas, segundo Davidson, não percebemos o padrão, como sustenta Dennett. Além disso, especificamente em relação a tais estados mentais que são as atitudes proposicionais - segundo Davidson, estados inobserváveis —, mesmo que o comportamento manifesto das pessoas exiba certos padrões que podemos conhecer, isso não significa que as atitudes proposicionais sejam tais padrões perceptíveis. Logo, elas permanecem objetos fora do âmbito da percepção, assim como outras realidades mentais ou psíquicas.

O texto de Davidson introduz uma distinção entre perceber e perceber que - uma distinção similar àquela entre saber (ou conhecer) e saber quê. ${ }^{17}$ Uma pessoa pode conhecer Paris e não saber que Paris é também (chamada de) "A Cidade Luz", e vice versa. Essa distinção entre o que Russell denominou conhecimento por familiaridade ou conhecimento direto e o conhecimento por descrição, ou por testemunho, ou conhecimento proposicional (saber quê) é bastante clara tanto para a filosofia quanto para o saber comum. Mas não achamos que a distinção análoga, pressuposta por Davidson, seja tão clara assim. Ela não se sustenta, como veremos, pelo menos não da forma como Davidson a coloca.

Qual é, nesse caso, a diferença entre perceber um padrão e perceber que há um padrão em certa parte do mundo? Uma pessoa pode, por exemplo, saber muitas coisas sobre Paris sem nunca ter estado em Paris. Ou seja, jogando com as palavras, ela pode "conhecer" Paris sem conhecer Paris - porque pode ter adquirido todo seu conheci- 
mento de Paris de segunda mão ou por descrição, como diz Russell. E se ela conhece Paris, também pode prestar testemunho, pode fazer descrições e, assim, traduzir seu conhecimento direto e perceptivo de Paris em conhecimento proposicional, em um relato que possa transmitir informação a outras pessoas. "Perceber quê", pressuposto por Davidson, parece ser equivalente a "saber quê". Mas não é. Perceber que $x$ não é a versão proposicional de perceber $x$, ao contrário do caso de saber que Paris é uma cidade grande, que pode ser uma parte da versão proposicional de conhecer Paris. Cognitivamente, é claro que:

(1) perceber que (há o padrão) x (na coisa y) (como: perceber que a camisa de José é xadrez) decorre (ou pode decorrer) de:

(2) perceber $x$ (como: perceber o xadrez da camisa de José).

É claro que, tanto quanto (2), (1) é de caráter cognitivo; mas é muito diferente de:

(3) saber que x (como: saber que a camisa de José é xadrez).

Também (3) é de caráter cognitivo, obviamente. Mas a diferença entre (1), (2) e (3), enquanto estados ou processos cognitivos, é que (3) é conhecimento proposicional, (2) é conhecimento por familiaridade, ou conhecimento direto, e (1) é um estado de consciência reflexiva. Esses três estados cognitivos são completamente distintos, de tal modo que podemos ter (2) - e perceber $x$ - sem termos (1) - não percebermos que $x$. Podemos perceber o xadrez da camisa de José sem nos darmos conta de que percebemos que a camisa de José é xadrez, ou ainda: sem nos darmos conta do xadrez da camisa de José. Trata-se de um caso um tanto semelhante ao da visão cega e ao caso do relógio de Peirce. Mas, nesse caso do xadrez da camisa de José, o que ocorre é simplesmente que não estávamos prestando atenção à sua camisa, ou não estávamos prestando atenção em José etc. Mas, depois, se alguém nos perguntar como é a camisa que José estava usando em certa ocasião, podemos consultar algum meandro da memória e dizer que ela era xadrez. Podemos trazer à consciência uma percepção que se deu, mas da qual não nos tínhamos dado conta.

Curiosamente, há aqui um eco da ideia platônica de reminiscência. Há um conhecimento inconsciente que é trazido à consciência. A maiêutica realizada por meio de uma teoria sobre realidades abstratas seria aquela de nos ajudar a trazer à consciência algo que percebemos, mas que não percebemos que percebemos. Ou seja, por assim dizer, a percepção de realidades abstratas pode ser uma percepção de segunda ordem, já que pode ser realizada por meio de um estado de consciência reflexiva. Mas ela pode também ser uma percepção de primeira ordem, como quando, adotando a postura adequada, como sugere Dennett, percebemos certos padrões. 


\section{A percepção social}

Para percebermos quaisquer realidades no mundo é preciso estarmos adequadamente aparelhados, como as discussões acima procuraram mostrar. Sempre haverá realidades que ficarão fora de nossas capacidades perceptivas, e algumas que ficarão fora das capacidades perceptivas de quaisquer sujeitos cognitivos, de qualquer espécie, obviamente. E, contudo, elas estarão lá, prontas para serem percebidas por outros. A percepção de determinadas realidades não é imediata, automática ou natural, digamos assim, isto é, ela não ocorre pelo simples fato de um sujeito estar com seu suposto aparato natural (físico ou neurofisiológico) adaptado para perceber tais realidades - aquele aparato que supostamente ele traz do útero materno. Se deixarmos de lado aquela demarcação rígida entre processos perceptivos e processos intelectuais, então podemos nos dar conta de que a percepção de determinadas realidades requer também certo aprendizado. O aparato natural para percebermos certas coisas inclui sua preparação especial, sua maturação em condições ambientais, condições que são também, algumas vezes, sociais. ${ }^{18}$

Esse é o caso da percepção de realidades abstratas, para voltarmos ao ponto de vista de Platão. Mas um caso mais trivial é sugestivo. Voltemos ao caso da visão das cores e consideremos um daltônico que não vê a diferença entre vermelho e verde. Seu aparato natural, digamos, aquele que ele traz do útero materno, não o habilita para isso. Mas um daltônico desse tipo, como ocorre em nossa sociedade, aprende, por exemplo, a discriminar as luzes vermelha e verde dos semáforos de trânsito. Ele aprende que o vermelho está no alto e que o verde está em baixo, depois do amarelo. É claro que se, por acaso, se inverterem essas posições, ele não será mais capaz de discriminar as diferentes luzes do semáforo. Em que sentido podemos dizer que esse daltônico não percebe a diferença entre o verde e o vermelho? Insistir que ele apenas infere a diferença entre essas duas cores é simplesmente, mais uma vez, ater-se àquela demarcação rígida entre percepção e conhecimento intelectual, ou entre percepção e crença.

Suponhamos que por uma espécie de mutação genética os pimentões vermelhos se tornem mortalmente venenosos para nós. Inicialmente, isso poderia ser catastrófico para aqueles que são apreciadores de pimentões, mas logo perceberíamos a diferença com base na cor. Nesse caso podemos dizer que inferimos que os pimentões vermelhos são venenosos? É claro que não. O que vai acontecer é que, diante de um pimentão vermelho, as pessoas vão dizer que percebem ali um pimentão venenoso, e não que elas percebem ali um pimentão e inferem que ele é venenoso. O que ocorre, obviamente, é que, depois de alguns casos (catastróficos ou não), vamos adquirir a crença de que os pimentões vermelhos são venenosos. ${ }^{19} \mathrm{E}$ por isso, quando estivermos vendo um pimentão vermelho à esquerda de um pimentão verde, diremos que percebemos ali um pimentão venenoso à esquerda de um pimentão não venenoso.

Principia 21(2): 251-289 (2017). 
O mesmo vai acontecer com o daltônico que aprendeu que o farol vermelho fica no alto e, quando mudar de cidade ou de país, por exemplo, tiver de rever sua crença e aprender que, ao contrário, naquela localidade o farol vermelho fica em baixo.

A objeção que se poderia ainda levantar aqui é que, no caso do daltônico, a suposta "percepção" é contextual, o que não é o caso com nossa visão de tricromatas dos pimentões vermelhos e venenosos, à esquerda, e verdes e não venenosos à direita. Mas para isso, de fato, é preciso recorrer a outra forma de demarcação, e sustentar que a percepção é um processo não contextual. A nosso ver, isso seria voltar a uma forma de sensualismo ingênuo que não se sustenta se considerarmos as pesquisas mais recentes no domínio da neurofisiologia da percepção, como alguns dos casos que examinamos antes sugerem. Essa forma ingênua de sensualismo continua a sustentar, por sua vez, contra evidências empíricas, que há uma distinção rígida, baseada na natureza das coisas, entre percepção e crença ou conhecimento intelectual.

A percepção social é a percepção, por exemplo, de padrões característicos de determinados contextos sociais, como aqueles que podem ser percebidos quando estamos diante de uma instituição. Aqui, uma concepção reducionista sustentaria que o que percebemos é o comportamento dos indivíduos ligados a tal instituição. Mas isso também não se sustenta, pois se pode também argumentar que não percebemos o comportamento das pessoas, mas apenas seus movimentos. Perceber o comportamento de alguém já requer a intervenção de um processo interpretativo. Em toda a tradição behaviorista, tanto da parte de psicólogos profissionais, quanto de filósofos, sempre se sustentou que o comportamento manifesto é algo observável, ao contrário dos estados mentais ou psíquicos a ele ligados - e por isso mesmo o comportamento seria o objeto privilegiado cientificamente para entendermos o mentalismo humano. Mas, de fato, se uma demarcação rígida entre percepção e crença for mantida, o que é observável não é o comportamento, mas os movimentos das pessoas. Por que certos movimentos em certos contextos contam como comportamento e, em outros, não? ${ }^{20}$ E quando, em determinado contexto, todos os observadores concordarem que há um caso de comportamento, por que diríamos que inferimos tal comportamento, em vez de dizermos que o percebemos? Não faríamos isso.

Os padrões relativos ao comportamento das pessoas pertencentes a determinada instituição são realidades abstratas. Juntamente com Dennett, devemos dizer que eles são reais e que são perceptíveis. Não há por que dizermos que percebemos o comportamento (ou o movimento) das pessoas e inferimos a presença de uma instituição, ou que inferimos o padrão, ou que percebemos que há um padrão, como quer Davidson. O que percebemos diretamente é a instituição, embora isso não seja perceptível para aqueles que não estejam aparelhados convenientemente. O que é então preciso para percebermos uma realidade social? É preciso um aprendizado prévio, assim como no caso do daltônico diante do semáforo ou naquele possível caso dos tricromatas diante de pimentões vermelhos e venenosos - e como no caso de perce- 
ber corretamente as emoções das pessoas através de seus movimentos faciais. Mas, dado isso, a discussão deixa de ser sobre uma suposta e tão problemática distinção entre percepção e crença, mas sobre graus de abstração.

Consideremos as seguintes afirmações feitas por alguém:

(4) Vi José trabalhando.

(5) Vi José escrevendo um artigo.

(6) Vi José movendo seus dedos sobre o teclado do computador.

Ora, não é o caso de dizermos que a pessoa viu apenas o que está afirmado em (6), que ela viu apenas os movimentos dos dedos de José sobre o teclado. Essa pode até ser para nós uma suposta visão não interpretada, dada nossa natureza afeita a corpos, como nos diria Quine; e, em certo sentido, é claro que as visões relatadas em (4) e (5) são interpretadas, ${ }^{21}$ uma vez que são certas crenças prévias que permitem dizer que:

(7) Mover os dedos sobre o teclado do computador = escrever; e:

(8) Escrever = trabalhar.

Mas em nenhum sentido razoável se poderia argumentar que aquela pessoa que faz aqueles três relatos - (4), (5) e (6) - não percebeu José trabalhando e não percebeu José escrevendo. Dadas as equivalências interpretativas de (7) e (8), os relatos (4), (5) e (6) são alternativas que diferem apenas em grau de abstração. E mesmo que consideremos que o grau de abstração de (6) seja zero, pois se trata de descrever relações visíveis entre corpos ou entidades concretas, e mesmo que (4) seja mais abstrato que (5), em todos os três casos temos percepções.

Talvez Davidson sugerisse a essa altura que, ao contrário, teríamos:

(9) Percebi que José estava trabalhando.

(10) Percebi que José estava escrevendo.

(11) Percebi os dedos de José se movendo sobre o teclado do computador.

Mas, nesse caso, a única diferença entre (9) e (10), de um lado, e (11), de outro, seria que os dois primeiros são relatos de estados de consciência reflexiva. A pessoa se deu conta de que José trabalhava, que escrevia. E o relato (11) pode ser um relato que não chegou à consciência no momento da percepção. Como dissemos antes, perceber que e perceber são diferentes estados cognitivos. E (9) não substitui (4), nem (10) substitui (5).

Um argumento definitivo, contudo, contra a percepção de realidades abstratas consistiria em dizer que, mesmo admitindo graus de abstração, há um limite para a percepção de abstrações. Pode-se argumentar que o trabalho, por exemplo, é uma

Principia 21(2): 251-289 (2017). 
realidade abstrata perceptível porque ela sempre terá um correlato concreto. "Trabalhar" sempre poderá ser traduzido - e, logo, reduzido - para "escrever", "carpir", "lavar louça" etc. E, por sua vez, cada um desses, como "escrever", por exemplo, sempre poderá também ser reduzido, conduzindo a: "mover os dedos sobre o teclado do computador", "mover a caneta sobre o papel" etc. Contudo, prossegue o argumento definitivo, certas supostas realidades abstratas não podem ser instanciadas em circunstância concretas - essas, sim, claramente perceptíveis. E esse seria então o caso das crenças e outros estados mentais, assim como das realidades sociais ou culturais, como instituições, valores compartilhados, costumes etc. E, por fim, mesmo que se sustente, por exemplo, que crer que José escreve um artigo está instanciado na percepção dos dedos de José a se moverem sobre o teclado do computador, e que crer que José pertence a determinada instituição, sua universidade, por exemplo, está instanciado no comportamento manifesto de José, ainda assim certas outras possíveis realidades abstratas - como números e figuras geométricas — não podem ser percebidas, pois não há delas instanciações possíveis.

Ora, de um lado, esse argumento definitivo já concedeu muito do que desejávamos, pois já admite que percebemos crenças e instituições, por exemplo. Em última instância, o argumento se atém à ideia de Carnap, no Aufbau, de que todo objeto cultural deve possuir uma documentação concreta e que todo objeto heteropsicológico deve estar correlacionado com o comportamento manifesto. Por outro lado, contudo, esse argumento definitivo erra ao supor que não há instanciações concretas de números e figuras geométricas. Por exemplo, $\bullet$ e $\Delta$ são instanciações concretas do número dois e do triângulo euclidiano, que também estão instanciados pelos dois pimentões antes mencionados e por um triângulo de sinalização de tráfego, por exemplo.

Entretanto, num último esforço, quem apresenta esse argumento definitivo ainda pode dizer que não percebemos o número dois, mas dois pequenos círculos pretos, nem percebemos o triângulo euclidiano, mas um triângulo, ainda que essas sejam instanciações concretas dessas entidades matemáticas. E, então, voltando aos casos da instituição, da crença e das emoções, pode dizer que não percebemos essas coisas, mas os comportamentos manifestos correspondentes a elas, ou então os movimentos correspondentes.

A resposta a esse último esforço do argumento definitivo, contudo, é relativamente fácil. Em todos esses casos, temos percepções interpretadas, como dissemos antes. É claro que sem o aparato conceitual adequado, não poderemos perceber que José trabalha, nem que ele pertence a determinada instituição, nem que possui determinadas crenças, nem que está em certos estados emocionais. Mas, dado esse aparelhamento conceitual, dada a perspectiva que ele nos oferece, em nenhum sentido razoável podemos dizer que não percebemos (mas inferimos) o trabalho de José, sua instituição e suas crenças e emoções. Pois, em última instância, se dissermos isso, então teremos também que dizer que as cores que vemos - e que também são re- 
alidades perspectivistas para nós, tricromatas - são também imperceptíveis. Mas elas, obviamente, são perceptíveis, embora apenas do ponto de vista tricromata, apenas dado o aparelhamento óptico-cortical dos tricromatas. Ora, igualmente, já que não estamos sustentando uma demarcação rígida entre percepção e conhecimento intelectual, emoções, crenças e instituições também são entes de percepção, e não de pensamento, dado nosso aparelhamento cognitivo, aquele que permite as percepções (mais) interpretadas.

O fato de admitirmos que há percepções interpretadas, como dissemos antes, não significa que haja percepções não interpretadas. Essas últimas são apenas aquelas percepções que, por sua vez, não são por alguém percebidas como interpretadas. Ora, quem nada sabe sobre as teorias atuais sobre a visão das cores pode supor que sua visão das cores é completamente isenta de interpretação, isto é, de perspectivismo. Há interpretação sempre que determinada cognição envolver alguma perspectiva. E Kant já nos ensinou há muito tempo que toda cognição é de natureza perspectivista. Esse perspectivismo é certamente claro no caso da percepção de instituições, e talvez menos claro no caso da percepção de crenças e emoções, menos ainda no de cores, e muito menos no de corpos.

Mesmo assim, por fim, ainda se poderia dizer, retomando o argumento definitivo acima considerado, que não haveria nenhum perspectivismo em nossas cognições matemáticas - pace Kant e os intuicionistas. Independentemente desse tipo de neokantismo em relação aos fundamentos ontológicos da matemática, tomemos o caso mais simples de ensinarmos a alguém os números naturais, como temos feito com as crianças há séculos. Fazemos isso de diversas maneiras, como, por exemplo, usando os dedos das mãos para instanciarmos os números de 1 a 10. Suponhamos que a criança a quem ensinamos isso, por meio de dois dedos destacados em uma das mãos e três na outra, se dê conta da diferença entre o 2 e o $3 .^{22}$ Mas se a criança deu o passo decisivo no aprendizado de matemática, porque tem aparato cognitivo para isso o que não é possível para, por exemplo, cães, e gatos, e outros animais —, então ao perceber dois dedos destacados em uma mão e três dedos na outra, ela também percebeu o 2 e o 3 . Outros animais, fora os humanos, realmente perceberão apenas os dedos.

De fato, a dificuldade maior que as entidades matemáticas representariam para nossa posição decorre do fato relativamente entrincheirado na cultura filosófica e científica, desde que se aceite o realismo matemático, de que essas entidades abstratas não são objetos do Mundo 3 do qual Popper fala. Isto é, elas não seriam invenções nossas, tal como Popper supõe que são todos os objetos abstratos do Mundo 3. A autonomia das entidades matemáticas parece estar além de qualquer autonomia (relativa) que, segundo Popper e outros perspectivistas, estejamos dispostos a conceder aos objetos culturais em geral. Se são reais, como os plantonistas desejam, as entidades matemáticas possuem uma autonomia absoluta, assim como as realidades 
físicas. É o que se pensa via de regra. Mas talvez o estudante de nível médio não pense assim quando lhe ensinamos a noção de número imaginário, dentre outras noções matemáticas menos intuitivas para o senso comum. Esses números são necessários para resolvermos problemas mais complicados, como o da raiz quadrada de números negativos. E os próprios números negativos podem ter para o estudante certo ar de arbitrariedade. A vantagem da matemática em nos convencer da autonomia das entidades com as quais lida, adotando uma postura realista na matemática, é apenas que há melhores teorias matemáticas do que teorias para crenças, emoções e instituições. Mas há algum perspectivismo de qualquer forma.

A menção dos números imaginários pode parecer mais atrapalhar nossa argumentação geral aqui do que ajudar. E, para evitar isso, quem sabe possamos defender que apenas os números naturais e as figuras geométricas seriam reais. Mas, para evitar então mais dificuldades, pelo menos no caso específico da aritmética, talvez possamos argumentar que apenas as classes são reais - e resolveremos então toda a aritmética por meio de uma teoria de conjuntos, que é algo bem conhecido. Esse pode ser o caso, mas não vai comprometer nossa argumentação. Ao contrário, uma reforma ontológica drástica na matemática que preservasse apenas as classes, por exemplo, nos colocaria mais perto de tornar o realismo perspectivista aceitável e, associado a ele, o fato de que as entidades matemáticas também são entes de percepção. Pois é verdade que também podemos ensinar a noção de classe àquela criança por meio do artifício dos dedos das mãos destacados. E, igualmente, ela vai perceber duas classes ou coleções, uma binária e outra ternária. Ela perceberá que elas são diferentes, mas porque as percebeu, em primeiro lugar. As classes, assim como as instituições, são realidades perceptíveis, embora, como todas as entidades, sejam entes perspectivistas.

\section{Considerações finais: a ubiquidade dos padrões}

O correlato necessário de sustentar que toda percepção é interpretada seria aquela hipótese segundo a qual toda interpretação é perceptiva, que todo pensamento está, por assim dizer, contaminado por percepções. E essa talvez seja uma hipótese sobre a natureza de nosso aparelho cognitivo que vá agradar muito aos simpatizantes do empirismo; no sentido contrário da relação, os racionalistas é que se agradam. Se não virmos como sustentar uma demarcação nítida entre percepção e pensamento, então essa será uma conclusão inevitável. E possivelmente tal hipótese estará de acordo com aquela de Quine de que temos um faro inato para identificar espécies naturais. E, seguindo Dennett, também podemos dizer que temos um faro inato para perceber padrões, o que nos conduz à percepção de realidades abstratas em geral. E, assim, esse seria também um viés cognitivo nosso.

Como vimos, a percepção de padrões é o passo decisivo para o conhecimento

Principia 21(2): 251-289 (2017). 
de realidades abstratas. De fato, há padrões por toda parte ou, mais precisamente, em tudo o que percebemos. Voltemos ao caso comum, expresso na fórmula que deu título a este texto: "a beleza está nos olhos de quem a vê". Ora, a beleza está no padrão percebido e por isso, certamente, está "nos olhos de quem a vê" ou, mais precisamente, na perspectiva que permite perceber esse padrão. É difícil explicar o que é a beleza de muitas coisas que vemos, para não falarmos da beleza, em sentido metafórico, de muitas outras coisas. O que é a beleza, no sentido moral, de um gesto? A beleza de um gesto, no sentido físico, contudo, é muito mais fácil de explicar, como, por exemplo, a beleza do gesto da bailarina que dança. Há um padrão, uma espécie de proporção e equilíbrio no gesto da bailarina. E se nos ativermos ao rosto da bailarina, supondo, obviamente, que ela seja uma dessas belezas incontestáveis, perceberemos o equilíbrio, a harmonia das formas de seu rosto, o padrão. Essa beleza é uma questão geométrica. É um padrão de volumes, de sombras e luzes.

É claro que há muito de cultural a ser pressuposto para considerarmos belo o gesto da bailarina, para considerarmos seu rosto de uma beleza incontestável. Há muito de intelectual nesse aparato cultural que nos permite perceber - e apreciar - essa beleza. Ela está, sem dúvida, em nossos olhos - e em nossos cérebros. Ela está em nossa mente, mas não apenas na mente psíquica dentro de nossas cabeças. Essa beleza está também na cultura compartilhada, na mente social e estendida na qual nossa mente individual e psíquica foi formada. A beleza está nos olhos de que a vê, é claro, porque está também no mundo. A beleza é um padrão muito abstrato e intelectualmente refinado, mas é algo que realmente vemos quando olhamos para a bailarina, para seu rosto e seu gesto ao dançar. Percebemos a bailarina, percebemos seu rosto e seu gesto, mas percebemos também sua beleza.

Podemos imaginar seres que não possuam um viés cognitivo - intelectual e perceptivo - para identificar padrões. Sendo animais, esses seres provavelmente não sobreviveriam num planeta como o nosso. Mas vamos supor que eles pudessem existir. Podemos então concluir que eles não perceberiam a beleza nem do gesto da bailarina, nem de seu rosto. $\mathrm{E}$ talvez - e provavelmente - também não percebessem sequer o próprio rosto da bailarina. $\mathrm{O}$ rosto é um padrão também. Identificar rostos e ler rostos é também uma de nossas atividades cognitivas fundamentais para nos movermos no meio social, como mostram pesquisas como a de Paul Ekman, já citada (cf. Ekman e Friesen 2003). A linguagem corporal de expressões faciais e de gestos é um domínio de padrões, como toda linguagem. E, como toda linguagem, é também um domínio de realidades abstratas. Quando olhamos a bailarina, vemos seu gesto, seu rosto e sua beleza - e vemos igualmente o Belo, como podemos ver também outro universal, o Bem, ao percebermos a beleza de um gesto no sentido moral. 


\section{References}

Abbott, E. A. 1992 [1884]. Flatland. A Romance of Many Dimensions. Nova York: Dover.

Barreto, A. H. de L. 2010. Contos completos. São Paulo: Companhia das Letras.

Carnap, R. 1967. The Logical Structure of the World. Berkeley e Los Angeles: University of California Press.

1995 [1934]. The Unity of Science. Bristol: Thoemmes Press.

Darwin, C. 2009 [1872]. The Expression of Emotions in Man and Animals. Cambridge: Cambridge University Press.

Davidson, D. 2001. Indeterminism and Antirealism. Subjective, Intersubjective, Objective. Oxford: Clarendon Press, pp.69-84.

Deacon, T. W. 1997. The Symbolic Species. The Co-evolution of Language and the Brain. Nova York e Londres: Norton.

- 2013. Incomplete Nature. How Mind Emerged from Matter. Nova York e Londres: Norton.

Dennett, D. C. 1991. Real Patterns. The Journal of Philosophy 88(1): 27-51.

. 2002. Seeing Is Believing - Or Is It? In: Noë; Thompson (orgs.) (2002), pp.481-485.

Dutra, L. H. de A. 2001. O estatuto cognitivo dos conceitos psicológicos. Cadernos de história e filosofia da ciência, série 3, 11(2): 89-129.

- 2006. A Ciência e o Conhecimento Humano como Construção de Modelos. Philósophos 11(2): 271-310.

- 2006b. Ação, Comportamento e Movimento. Manuscrito 29(2): 637-675.

- 2013. Pragmática de modelos. Natureza, estrutura e uso dos modelos científicos. São Paulo: Edições Loyola.

— 2017. Autômatos geniais. A mente como sistema emergente e perspectivista. Brasília: Editora da UnB [no prelo].

Ekman, P.; Friesen, W. V. 2003. Unmasking the Face. A Guide to Recognizing Emotions from Facial Clues. Cambridage, Mass.: Malor Books.

Freud, S. 1975 [1927]. The Future of an Illusion. Nova York: Norton.

Giere, R. N. 2006. Scientific Perspectivism. Chicago e Londres: The University of Chicago Press.

Hassin, R. R.; Uleman, J. S.; Bargh, J. A. (orgs.). 2005. The New Unconscious. Oxford: Oxford University Press.

Hume, D. 2007 [1777]. An Essay Concerning Human Understanding. Oxford: Oxford University Press.

Mlodinow, L. 2012. Subliminal. How Your Unconscious Mind Rules Your Behavior. Nova York: Pantheon Books.

Noë, A.; Thompson, E. (orgs.). 2002. Vision and Mind. Selected Readings in the Philosophy of Perception. Cambridge, Mass.: The MIT Press.

Popper, K. R. 1959. The Logic of Scientific Discovery. Londres: Routledge.

- 1972. Objective Knowledge. An Evolutionary Approach. Oxford: Oxford University Press.

Quine, W. van O. 1961[1953] From a Logical Point of View. Logico-Philosophical Essays. 2a. ed. revista. Nova York: Harper \& Row.

- 1966. Ways of Paradox and Other Essays. Nova York: Random House.

- 1969. Ontological Relativity and Other Essays. Nova York: Columbia University Press.

Principia 21(2): 251-289 (2017). 
1992. Pursuit of Truth. Cambridge, Mass.: Harvard University Press.

1995. From Stimulus to Science. Cambridge, Mass.: Harvard University Press.

Werner, J. S.; Chalupa, L. M. (orgs.) 2014. The New Visual Neurosciences. Cambridge, Mass., e Londres: The MIT Press.

Luiz HenRique De ARAúJo Dutra

$\mathrm{UFSC} / \mathrm{UnB} / \mathrm{CNPq}$

lhadutra@gmail.com

RECEIVED: 04/12/2017

ACCEPTED: $15 / 01 / 2018$

\section{Notas}

${ }^{1}$ Cf., por exemplo, Ekman e Friesen 2003. Paul Ekman é um renomado estudioso do assunto, tendo diversas outras obras sobre isso. O tema da expressão das emoções já é tratado por Darwin (2009 [1872]). A hipótese de Darwin, confirmada experimentalmente por Ekman e seus associados, é que as expressões faciais são universais na espécie humana, dando perfeito fundamento científico à ideia de que o rosto é o espelho da mente.

${ }^{2}$ Uma distinção comum da parte de diversos filósofos é aquela entre modalidades do universal, digamos, isto é, de que, em princípio o que é universal é o que diz respeito a todos de uma subclasse. Esse universal relativo, por assim dizer, se distingue do universal absoluto, que seria aquilo que diz respeito a todos os indivíduos de determinado tipo. Karl Popper (1959) é um dos autores que sustenta essa distinção. Nesses termos, a discussão a seguir que trata da distinção entre percepções e pensamentos (ou crenças, valores etc.) diz respeito à associação tradicional entre as percepções e o que é absolutamente universal, sendo que os pensamentos poderiam ser, no máximo, de um tipo de universalidade relativa (a determinada subclasse).

${ }^{3}$ É claro que todos os grupos humanos - e, logo, todos os indivíduos humanos - possuem crenças e valores, mas, obviamente, nem sempre os mesmos - e, de fato, frequentemente, muito distintos - valores e crenças.

${ }^{4}$ Embora ainda utilizado em aulas de genética básica, isso tem sido contestado e apontado como uma falsa crença científica. Contudo, nosso argumento não se afeta, uma vez que outros exemplos seriam possíveis.

${ }^{5} \mathrm{O}$ realismo perspectivista é defendido por Ronald Giere (2006), que utiliza justamente o caso da visão das cores para explicar sua posição. Giere, contudo, aplica o realismo perspectivista apenas ao caso dos constructos teóricos, como modelos, conceitos, teorias científicas etc. Ele não o estende a outros objetos abstratos (ou culturais) - aqueles objetos que Karl Popper (1972) localizou no Mundo 3. Assumimos a mesma posição ontológica tanto de Popper como de Giere, mas pretendemos estender o realismo perspectivista a todos os objetos culturais (cf. Dutra 2013) e, como vamos argumentar adiante neste texto, também aos objetos de percepção.

${ }^{6}$ Devemos esclarecer um ponto importante desde logo. Tal como Carnap (1967) argumenta, todos os objetos que ele denomina culturais e que, em seu sistema construcional, são construídos a partir ao mesmo tempo de objetos físicos e de objetos heteropsicológicos, são objetos também de natureza física. Carnap chamou isso de documentação do objeto cultural. Suponhamos um exemplo comum, a saber, uma nota de dinheiro. Trata-se de um objeto

Principia 21(2): 251-289 (2017). 
cultural e, nesse sentido, abstrato, cuja realidade enquanto valor monetário só pode ser reconhecida por determinados indivíduos, daí sua patente existência perspectivista. Mas, na terminologia utilizada por Carnap, papel e tinta são a documentação desse objeto cultural. Na terminologia emergentista do realismo perspectivista que adotamos (cf. Dutra 2017, cap. 3), papel e tinta, de um lado, e, de outro, determinados estados mentais (no sentido mentalista tradicional, isto é, estados psíquicos) dos indivíduos humanos são as condições de base da emergência do objeto cultural. Mas, mesmo possuindo então uma documentação ao mesmo tempo física e psíquica, como diria Carnap, o objeto cultural é de natureza abstrata. Uma instituição, por exemplo, que reconhecemos facilmente como um objeto abstrato, tem como condições de base (ou documentação) determinadas formas do comportamento manifesto de certos indivíduos humanos e os respectivos estados mentais (ou neurofisiológicos, se quisermos) internos a esses indivíduos. Assim, embora as condições de base de um objeto cultural sejam concretas (físicas e psíquicas), o próprio objeto, como um emergente, é abstrato. Há aqui, de todo modo, uma questão ontológica polêmica, pois se poderia argumentar que os objetos tipicamente abstratos (como números, figuras geométrica e classes) não possuem condições de base concretas, mas que seriam puramente abstratos. Mas, na filosofia da matemática, sabemos que os intuicionistas (seguindo Kant, aliás) argumentam que os objetos matemáticos possuem condições de base psíquicas, para utilizarmos a expressão dos emergentistas. A polêmica ontológica aqui mencionada envolve a noção de graus de abstração, que é algo bastante confuso - e duvidoso - se tomado no sentido platônico tradicional, isto é, admitindo realidades abstratas que não possuam quaisquer condições de base concretas.

${ }^{7}$ Outro ponto que merece um esclarecimento inicial, sem dúvida, é nosso uso do termo "mental", que desvia do uso mentalista tradicional (cf. Dutra 2017, cap.2). No sentido do mentalismo dualista tradicional (mesmo para o dualismo puramente conceitual, e não metafísico, um dualismo, por exemplo, apenas de propriedades), "mental" quer dizer interno ao indivíduo humano. Nesse sentido é que empregamos o termo "psíquico". Da perspectiva do emergentismo perspectivista a respeito do mentalismo humano, "mental" envolve também elementos ambientais, externos ao ser humano, portanto, e não apenas internos (ou psíquicos, ou neurofisiológicos).

${ }^{8}$ Para os detalhes anatômicos e neurofisiológicos, cf., por exemplo, Werner e Chalupa 2014.

${ }^{9}$ Apenas para citarmos um autor que tem explorado essa linha de argumentação, mesmo sem entrar nos detalhes de sua teoria, cf. Deacon 1997; 2013.

${ }^{10}$ Esse tema é bem conhecido e, de fato, lugar comum na filosofia da ciência, sendo que diversos autores eminentes nessa área podem ser citados. Mas, para nos atermos a nomes já mencionados, cf. Popper (1959), e outras de suas obras, assim como o próprio Giere (2006), que defende o perspectivismo científico como o razoável caminho do meio entre o realismo ingênuo e o relativismo.

${ }^{11}$ Além desse livro de Mlodinow, cujas ideias serão comentadas adiante, sobre o agora chamado "novo inconsciente", a noção fundamentada nos resultados recentes da neurofisiologia, podem-se consultar obras como Hassin et al., 2005. Voltando ao caso citado inicialmente de lermos os estados mentais das pessoas em suas expressões faciais, podemos dizer que, embora não tenhamos um conhecimento sistemático e, portanto, consciente, para fazer isso, em parte o fazemos de maneira inconsciente, isto é, de forma subliminar percebemos pelas expressões faciais os estados mentais das pessoas. 
${ }^{12}$ Quine também diz em outra parte (1966, p.211) que embora os objetos físicos, assim como as partículas e outros constructos teóricos, sejam entidades hipotéticas, é para os objetos físicos que nos voltamos quando há alguma crise teórica e, logo, ontológica. (Cf. também Dutra 2001, p.118.) Em outros textos (como os artigos "Sobre o que há" e "Dois dogmas do empirismo"; respectivamente Quine 1961, p.18 e 44), ele diz que os objetos físicos são ficções úteis e, em tal condição, comparáveis aos deuses de Homero, mas que, de qualquer forma, essas ficções que são os objetos físicos são mais úteis que outras por simplificarem o fluxo da experiência. E é claro que Quine está entendendo sempre por "experiência" aquilo que nos vem pelos cinco sentidos e de que temos consciência.

${ }^{13}$ Cf. seu "Sobre o que há" (Quine 1961, pp.1-19). Vale lembrarmos, contudo, tal como vamos comentar na sequência, que esse realismo de Quine deve ser sempre compreendido em associação com sua ideia de relatividade ontológica, tal como expressa em seu texto de mesmo nome (Quine 1969, pp.26-68).

${ }^{14}$ Mlodinow começa seu livro (2012, p.7s) comentando o interessante caso relatado por Charles S. Peirce de ter descoberto o ladrão de seu relógio durante uma viagem de navio por meio de um processo (provavelmente) subliminar. Peirce identificou o ladrão entre os membros da tripulação do barco, mas sem saber por que tinha certeza de que era aquele indivíduo. Esse seu conhecimento depois se confirmou por outros meios. O que mencionamos antes sobre a expressão facial das emoções também se ajustaria em parte a isso, uma vez que podemos não ter consciência de ler os rostos das pessoas em determinadas ocasiões, mas, mesmo assim, pautamos corretamente nosso comportamento a partir dessa percepção inconsciente dos correspondentes estados mentais das pessoas.

${ }^{15}$ O termo inglês "delusion" tem sido traduzido para "ilusão" ou mesmo "alucinação", mas, no sentido psicológico mais técnico, a melhor escolha em português é "delusão", embora seja pouco usual. São delusões típicas as ilusões dos sentidos, como, por exemplo, perceber algo que não está lá. Daí a proximidade dessa noção para com a discussão que estamos empreendendo.

${ }^{16}$ Cf., por exemplo, Dennett 2002, texto no qual o autor critica a demarcação radical entre percepção e crença (ou conhecimento). O volume todo no qual se encontra esse texto é uma boa obra de referência sobre o tema aqui discutido: cf. Noë e Thompson 2002.

${ }^{17}$ Como sabemos bem, em português, ao contrário do inglês, é preciso fazer essa adaptação terminológica, já que há dois verbos distintos: "saber" e "conhecer". Em inglês, a distinção é entre "to know" e "to know that" que costumamos traduzir justamente por "conhecer" e "saber quê". Trata-se daquela distinção entre conhecimento direto (ou perceptivo, se quisermos) e conhecimento proposicional.

${ }^{18}$ Por exemplo, as pesquisas sobre as expressões faciais das emoções e nossa capacidade de conhecê-las apropriadamente, como aquelas de Paul Ekman, já citadas, podem ajudar na prática de fazer isso, ainda que possamos intuitivamente fazê-lo por meio de processos subliminares. Algo semelhante pode ser o caso com as realidades abstratas. É claro que, estritamente falando, um estado psíquico ou neurofisiológico (como uma emoção) é diferente do estado muscular do rosto da pessoa que o expressa. Mas a mudança de perspectiva, nesse caso, consiste em considerarmos tanto o estado neurofisiológico ou psíquico quanto o estado muscular do rosto como duas etapas do mesmo processo. As pesquisas de Ekman sugerem exatamente que não é o caso de, primeiro termos a emoção e, depois, a expressarmos facialmente. Não deixar transparecer as emoções é possível se a pessoa for treinada para isso, o 
que, de fato, ocorre socialmente com muitos de nós, pelo menos com respeito a uma parte de nossas emoções.

${ }^{19}$ Nesse caso, ser vermelho, do ponto de vista perceptivo (ou observacional) fará parte de ser venenoso para pimentões. Isso nos faz remontar ao problema dos predicados projetáveis, levantado por Goodman, e à solução de Quine, dizendo que temos um faro inato para identificar espécies naturais. Não adiantaria contestar a afirmação de que, nesse caso, ser vermelho = ser venenoso (ou seja, que ser vermelho é para um pimentão indicativo de sua natureza), pois a equivalência só se eliminaria completamente por uma teoria última. Esse é o ponto de vista de Quine, afinal, em "Espécies naturais" (Quine 1969), e contestamos essa posição em Dutra 2006a.

${ }^{20}$ Discutimos a diferença (interpretativa) entre movimento, comportamento (do ponto de vista behaviorista) e ação (do ponto de vista mentalista) em Dutra 2006b.

${ }^{21}$ Antecipando uma objeção que será examinada adiante, não estamos admitindo aqui a distinção entre percepções interpretadas e não interpretadas — o que arruinaria toda a argumentação que estamos tentando construir. Como veremos, toda percepção é interpretada em alguma medida. O que pode ocorrer é o sujeito não se dar conta da interpretação envolvida, como no caso já mencionado da percepções das emoções por meio dos padrões faciais.

${ }^{22}$ Davidson talvez nos dissesse então a essa altura que essa criança percebe que 2 é diferente de 3 , mas que ela percebe apenas os dedos utilizados para isso. Acreditamos já ter vencido essa dificuldade anteriormente.

Principia 21(2): 251-289 (2017). 